\title{
Spiro Heterocycles
}

\section{An Enantio- and Diastereoselective Mannich/Pictet-Spengler Sequence To Form Spiro[piperidine-pyridoindoles] and Application to Library Synthesis}

\author{
Alejandra Riesco-Domínguez, ${ }^{[\mathrm{a}]}$ Nick van der Zwaluw, ${ }^{[\mathrm{a}]}$ Daniel Blanco-Ania, ${ }^{[\mathrm{a}]}$ and \\ Floris P. J. T. Rutjes*[a]
}

Abstract: A new tandem strategy based on a Mannich/PictetSpengler sequence has been developed and applied to the synthesis of a new small library (14 examples) of privileged compounds based on the spiro[piperidine-pyridoindole] core. The sequence proceeds by a diastereoselective Pictet-Spengler cy- clization after condensation of several tryptamine derivatives with three novel piperidin-4-ones containing the fluorinated substituents $\mathrm{F}_{1} \mathrm{CF}_{3}$ and $\mathrm{SF}_{5}$. The piperidin-4-ones were synthesized from readily available starting materials by an enantioselective multi-component organocatalytic Mannich reaction.

\section{Introduction}

Spirocyclic compounds have been increasingly exploited as lead compounds in the early phases of drug discovery due to their unique properties, such as intrinsic three-dimensionality, conformational restriction enhancing binding to a target and structural patentability. ${ }^{[1]}$ Over the past few years, various examples of natural compounds and synthetic drugs containing spiro-fused heterocycles have been discovered to possess relevant biological activities (Figure 1). ${ }^{[2]}$ In particular, nitrogen-containing spiro heterocycles have been identified as playing key roles in biological and pharmaceutical processes, ${ }^{[3]}$ rendering this framework an attractive building block for further research. Examples include iboluteine, an iboga-type indole alkaloid isolated from the Apocynaceae family, fluspirilene, an antipsychotic drug used for the treatment of schizophrenia, and fenspiride hydrochloride, an antitussive drug.
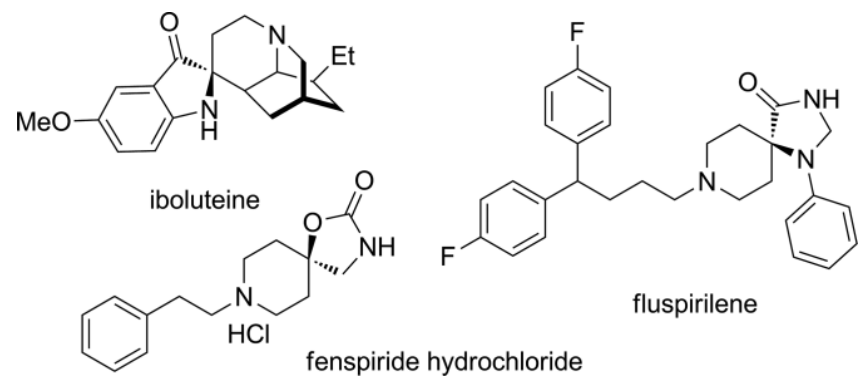

fluspirilene

fenspiride hydrochloride

Figure 1. Natural and synthetic active compounds containing the spiro-piperidine moiety.

[a] Institute for Molecules and Materials, Radboud University, Heyendaalseweg 135, 6525 AJ Nijmegen, The Netherlands E-mail: frutjes@science.ru.nl www.soc.science.ru.nl

(D) Supporting information and $O R C I D(s)$ from the author(s) for this article are available on the WWW under http://dx.doi.org/10.1002/ejoc.201601508.
In this regard, substituents at the 2- and 6-positions of the piperidine ring could be vital to modulate biological activity. ${ }^{[4]}$ Furthermore, it is well documented that the presence of fluorine atoms can greatly enhance the drug-likeness of small molecules. As a result of properties such as electronegativity, atom size and lipophilicity, the introduction of fluorine into small molecules can effectively alter their biological activity and bioavailability in comparison with their non-fluorinated counterparts. ${ }^{[5,6]}$

Inspired by previous piperidinone syntheses by our group, ${ }^{[7]}$ and in conjunction with current work on spirocyclic compound libraries within the framework of the European Lead Factory, ${ }^{[8]}$ we herewith report an enantio- and diastereoselective reaction sequence for the synthesis of spiro[2,6-diarylpiperidinepyridoindole] structures $\mathbf{7}$ and their utilization in the synthesis of a focused compound library also containing a variety of fluorine functionalities.

\section{Results and Discussion}

From a retrosynthetic point of view, the spiro[piperidinepyridoindole] core of compounds 7 can be generated from piperidin-4-one 4 and substituted indole derivatives through a diastereoselective Pictet-Spengler reaction (Scheme 1). The enantiopure piperidin-4-one $\mathbf{4}$ can itself be diastereoselectively obtained from $\beta$-amino ketone $\mathbf{3}$ by an intramolecular organocatalysed Mannich reaction. Lastly, amino ketone $\mathbf{3}$ should be accessible through an enantioselective organocatalysed threecomponent Mannich reaction with commercially available $p$-anisidine, 3,4-dimethoxybenzaldehyde and acetone.

The forward synthesis commenced with the preparation of protected $\beta$-amino ketone $\mathbf{1}$, as previously reported by our group. ${ }^{[7]}$ Compound 1 was obtained in $61 \%$ yield and $>99 \%$ ee through a multi-component L-proline-catalysed Mannich reaction. ${ }^{[7,9]}$ We selected compound $\mathbf{1}$ for the synthesis of this 


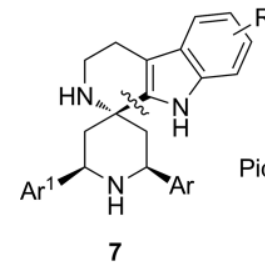

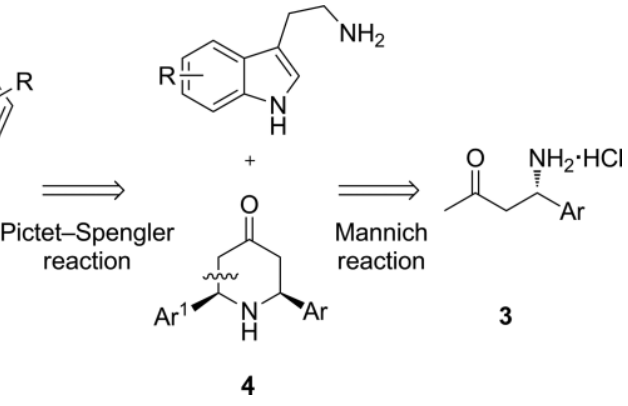

Scheme 1. Retrosynthesis of the spiro[piperidine-4, $1^{\prime}$-pyrido[3,4-b]indole] framework.

library due to the high relevance of the 3,4-dimethoxyphenyl group in nature and active drugs. ${ }^{[10]}$ From compound 1, two possible synthetic routes for the synthesis of 2,6-disubstituted piperidin-4-ones were envisioned (Scheme 2). Early efforts were focused on the synthesis of $p$-methoxyphenyl (PMP) protected piperidinones $\mathbf{2}$ in a one-pot procedure by a Mannich cyclization.

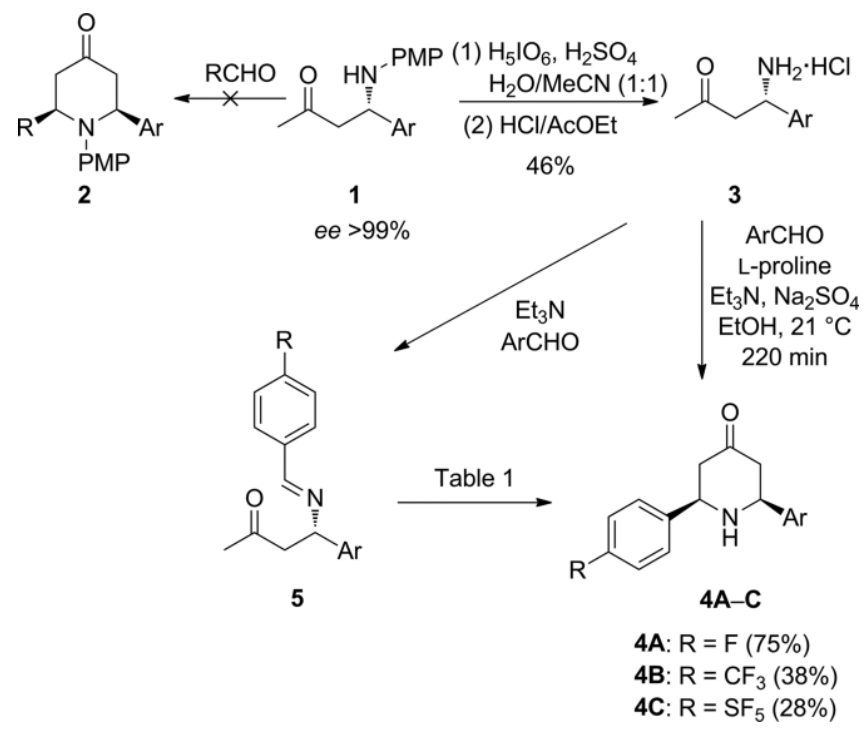

Scheme 2. Strategy for the synthesis of piperidin-4-one.

This approach involved the synthesis of the scaffold, which proved a challenge owing to the high level of steric hindrance arising from the three contiguous substituents. ${ }^{[11]}$ In our efforts to synthesize product $\mathbf{2}$, protected amine $\mathbf{1}$ was treated with several aldehydes in the presence of various catalysts and under a range of temperatures (see the Supporting Information). Unfortunately, none of these conditions led to the desired $\mathrm{N}$-protected piperidin-4-one 2. Owing to these difficulties, we then chose to synthesize the unprotected scaffold $\mathbf{4}$ with reduced steric hindrance (Scheme 2). To this end, the N-PMP amine 1 was deprotected by employing $\mathrm{H}_{5} \mathrm{IO}_{6}$ under acidic conditions to afford the corresponding product 3 in $46 \%$ yield. ${ }^{[12]}$ Subsequently, the free amino ketone $\mathbf{3}$ was treated with triethylamine and 4-fluorobenzaldehyde to afford imine $5(R=F)$. ${ }^{1} \mathrm{H}$ NMR analysis of the reaction mixture showed not only imine formation, but also the presence of a side-product, which could not be characterized, and the cyclized product 4A. Several reaction conditions were investigated to achieve the full conversion of imine 5 into the desired product 4A (Table 1). The conditions previously reported by $\mathrm{us}^{[7]}$ for these types of cyclizations were unsuccessful (Table 1, Entry 4). After further investigation, we found that full conversion to the cyclized product 4A could be achieved when using L-proline as the catalyst (Table 1, Entry 6).

Table 1. Reaction conditions employed to optimize the synthesis of $\mathbf{4 A}$.

\begin{tabular}{ccccc}
\hline Entry & Reagent (equiv.) & Solvent & $T\left[{ }^{\circ} \mathrm{C}\right]$ & Ratio 5/4A \\
\hline 1 & $\mathrm{Et}_{3} \mathrm{~N}(1)$ & $\mathrm{Et}_{3} \mathrm{~N} / 1,2-\mathrm{DCE}^{[\mathrm{a}]}$ & $21-60$ & $3.3: 1$ \\
2 & $\mathrm{KOtBu}(0.2)$ & $\mathrm{THF}$ & $21-70$ & $2: 1$ \\
3 & $\mathrm{Et}_{3} \mathrm{~N}(0.5)$ & $1,2-\mathrm{DCE}^{[\mathrm{a}]}$ & 40 & $3.3: 1$ \\
4 & $\mathrm{CSA}(1.2)$ & $1,2-\mathrm{DCE}^{[\mathrm{a}]}$ & 60 & $1.7: 1$ \\
5 & $\mathrm{TFA}(1.2)$ & $\mathrm{CH}_{2} \mathrm{Cl}_{2}$ & 21 & $0.3: 1$ \\
6 & L-proline (0.2) & $\mathrm{MeCN}^{2}$ & 21 & $0: 1$ \\
\hline
\end{tabular}

[a] 1,2-DCE = 1,2-dichloroethane.

In addition, ${ }^{1} \mathrm{H}$ NMR analysis of the reaction mixtures showed the existence of a slow equilibrium between imine $\mathbf{5}$ and $c y-$ clized product 4A under certain conditions, which led to different ratios of products depending on the temperature. In this manner, we observed that at low temperatures the formation of $\mathbf{4 A}$ was favoured, whereas at room temperature imines $\mathbf{5}$ and $\mathbf{6}$ were the major compounds in the reaction mixture. The presence of 5 and 6, 4-fluorobenzaldehyde and 3,4-dimethoxybenzaldehyde confirmed the existence of an equilibrium between compounds $\mathbf{4 A}, \mathbf{5}$ and $\mathbf{6}$ (Scheme 3).

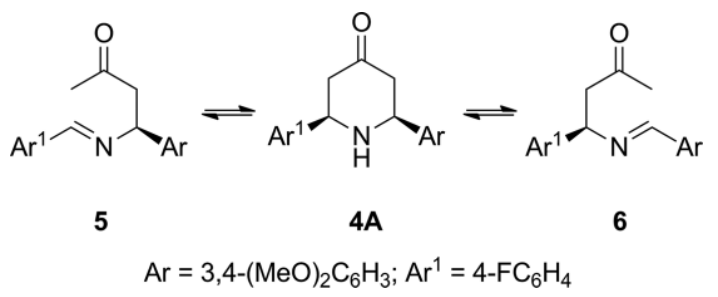

Scheme 3. Equilibria between $\mathbf{4 a}$ and imines 5 and $\mathbf{6}$

Following the optimization of the two-step synthesis of $\mathbf{4 A}$, a one-pot procedure for the preparation of the cyclized product directly from $\mathbf{3}$ was investigated. Thus, amine hydrochloride $\mathbf{3}$ was treated with $\mathrm{Et}_{3} \mathrm{~N}$ and anhydrous $\mathrm{Na}_{2} \mathrm{SO}_{4}$ in the presence of catalytic amounts of L-proline to afford the cyclized product $\mathbf{4 A}$ in $75 \%$ yield. In the same way, two additional cis-2,6-diarylpiperidin-4-ones, $\mathbf{4 B}$ and $4 \mathrm{C}$ containing $\mathrm{CF}_{3}$ and $\mathrm{SF}_{5}$ groups, were synthesized in yields of 38 and $28 \%$, respectively (Scheme 2). ${ }^{[13]}$ The mechanism for this diastereoselective cyclization by an intramolecular Mannich reaction is depicted in Scheme 4. First, the iminium ion species formed by the reaction of amine $\mathbf{3}$ and the corresponding aldehyde adopts the lowestenergy chair-like conformation in which the two hydrogen atoms are in pseudo-axial positions. Then the enamine, formed by L-proline and the ketone, attacks the iminium ion to form

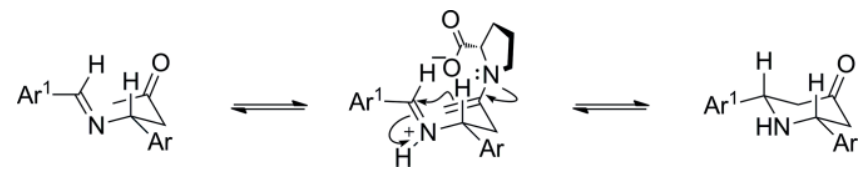

Scheme 4. Mechanism for the diastereoselective cyclization reaction. 
the final piperidin-4-one with a cis configuration with the two bulky aryl groups in equatorial positions. The cis stereochemistry of the products was confirmed by NOESY studies.

With the core scaffolds $\mathbf{4 A - C}$ in hand, we focused on the development of a new library of spiro compounds based on the derivatization of the ketone by the classic Pictet-Spengler reaction. ${ }^{[14]}$ Initially, 3-methoxy-, 3,4-dimethoxy- and 3-fluorophenethylamine were selected as test substrates (Scheme 5). ${ }^{[15]}$

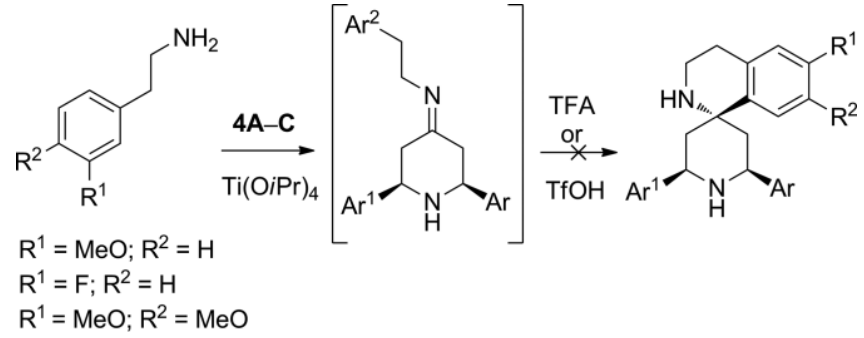

Scheme 5. Reactions of the piperidin-4-ones $\mathbf{4 A - C}$ with 2-phenylethylamines.

Test reactions without catalyst failed to achieve full conversion into the corresponding imines. However, after thorough investigation (see the Supporting Information), the reactions in the presence of $\mathrm{Ti}(\mathrm{O} i \mathrm{Pr})_{4}$ showed complete conversion. When performing the subsequent Pictet-Spengler reaction using both TFA and TfOH as promoters, however, no cyclized product was observed in any of the reactions.

Based on these preliminary results, the more reactive tryptamine was chosen as the model starting substrate (Table 2). The reactions of $\mathbf{4 A - C}$ with tryptamine were carried out in dichloromethane in the presence of $4 \AA$ molecular sieves, which smoothly afforded the imine intermediate. The addition of TFA at $0{ }^{\circ} \mathrm{C}$ then led to the diastereoselective formation of compounds $\mathbf{7 A a}-\mathbf{C a}$ in moderate yields (Table 2, Method A).

Further screening of the reaction conditions (see Table S7 in the Supporting Information) led us to conclude that optimal conversion into the imine could be achieved by the reaction of the selected amine with $\mathrm{Ti}(\mathrm{OiPr})_{4}$ (1.3 equiv.) in the presence of $\mathrm{Et}_{3} \mathrm{~N}$ (1.2 equiv., only for substrates delivered as the hydrochloride salt) in THF at room temperature. As previously stated, the addition of TFA at $0{ }^{\circ} \mathrm{C}$ then successfully delivered the desired Pictet-Spengler cyclization products. It is important to note that in all cases initially a mixture of the piperidin-4-one and imine was formed, and full conversion into the imine could not be achieved. By using these conditions, compounds 7Ab-Cd were synthesized in an average yield of $67 \%$. It is worth noting that $\mathrm{TfOH}$ was used as the acid in the synthesis of compounds 7 AdCd. In these instances, the use of TFA in different amounts (2.2, 4.0 and 7.0 equiv.) was not sufficient for the cyclization to take place. ${ }^{[16]}$ The resulting molecules, which contain three $\mathrm{N}-\mathrm{H}$ groups, were difficult to purify by standard silica gel column chromatography. For this reason, the products were isolated by inactivation of the silica with $\mathrm{Et}_{3} \mathrm{~N}$. Moreover, after column chromatography, an additional washing step was performed with $\mathrm{NH}_{4} \mathrm{OH}$ ( $25 \%$ in water) to remove residual triethylammonium salts.

To explain the diastereoselectivity we propose a rationale that is in accordance with the known reactivity of cyclohexan-
Table 2. Scope of the Pictet-Spengler cyclization reaction.

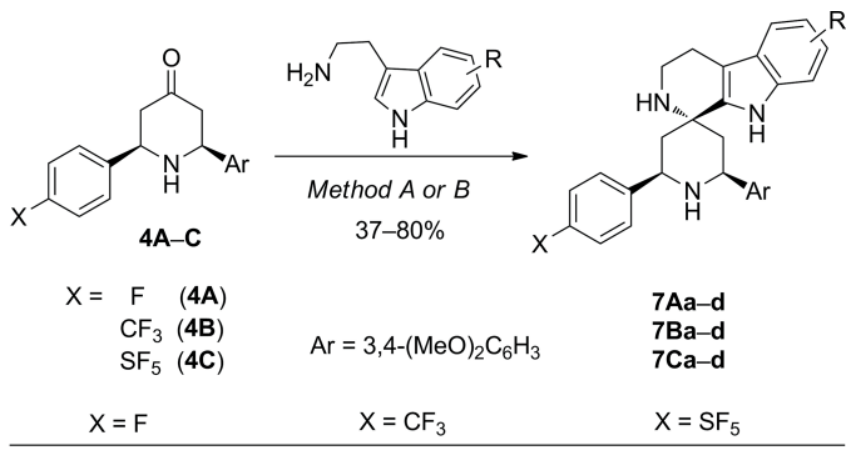<smiles>[Y17]C1C[C@@]2(C[C@H]([Al])N1)NCCc1c2[nH]c2ccccc12</smiles><smiles>[Mg]C1C[C@@]2(C[C@H](Br)N1)NCCc1c2[nH]c2ccccc12</smiles><smiles>ClC(Cl)(Cl)C(Cl)(Cl)Cl</smiles><smiles>Oc1ccc2c3c([nH]c2c1)[C@@]1(CC([Al])N[C@@H](Br)C1)NCC3</smiles>

$7 \mathrm{Ab}(B)$<smiles>Oc1ccc2[nH]c3c(c2c1)CCN[C@]31C[C@H]([Al])N[C@H]([18F])C1</smiles>

$7 \mathrm{Ac}(B)$

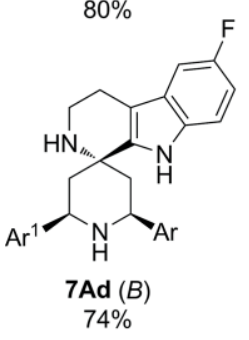

$41 \%$<smiles>COc1ccc2c3c([nH]c2c1)[C@@]1(CC([Al])N[C@H]([18C])C1)NCC3</smiles>
$7 \mathrm{Cb}(B)$

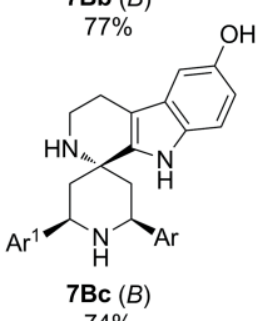

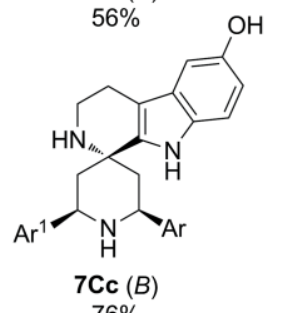

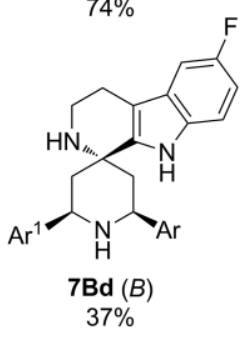

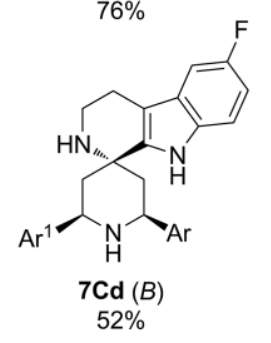

[a] Method A: reaction carried out in $\mathrm{CH}_{2} \mathrm{Cl}_{2}$ in the presence of molecular sieves, followed by the addition of TFA. Method $\mathrm{B}$ : $\mathrm{Ti}(\mathrm{OiPr})_{4}(1.3$ equiv.) in THF followed by the addition of TFA or TfOH. [b] Yield given based on recovered starting material (BORSM) for compounds $\mathbf{7 A b}-\mathbf{C d}$.

ones towards nucleophiles. ${ }^{[17]}$ The cyclization presumably proceeds through a chair-like transition state in which the indole ring exclusively attacks from the equatorial direction, which is the least hindered side (Scheme 6). 2D NMR studies (NOESY) confirmed the stereochemistry of products $\mathbf{7 A a}-\mathbf{C d}$.

To extend this library of compounds and to further expand the scope of the synthetic strategy, we synthesized compound 12 from indole-2-carbaldehyde, and compound $\mathbf{1 3}$ by using a smaller pyrrole-based heterocycle (Schemes 7 and 8). First, the Pictet-Spengler precursors $\mathbf{9}$ and $\mathbf{1 1}$ were synthesized starting 


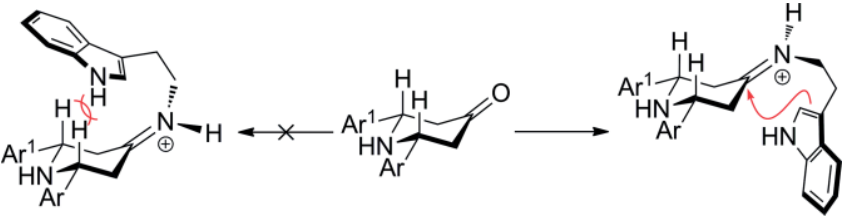

Scheme 6. Rationale for the diastereoselectivity of the Pictet-Spengler cyclization reaction.

from the commercially available indole-2-carbaldehyde and pyrrole-2-carbaldehyde by Henry reactions with nitromethane. ${ }^{[18]}$ Next, the intermediate nitro alkene $\mathbf{8}$ was reduced by using $\mathrm{LiAlH}_{4}$ in $\mathrm{Et}_{2} \mathrm{O}$ for the synthesis of $\mathbf{9}$, and nitro alkene $\mathbf{1 0}$ was reduced with a mixture of $\mathrm{NaBH}_{4} / \mathrm{NiCl}_{2}$ to give 11 (Scheme 7). ${ }^{[19]}$

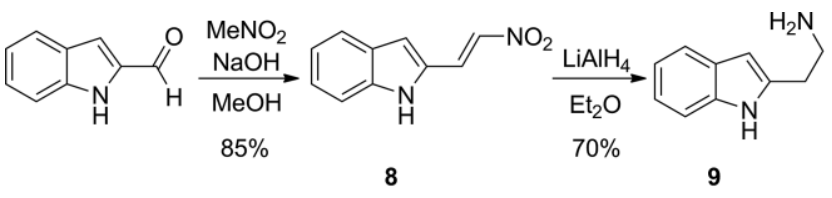

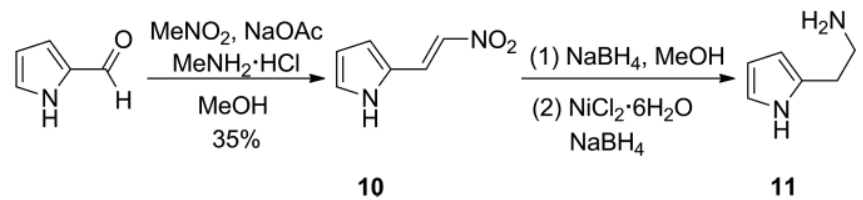

Scheme 7. Henry reaction and subsequent reduction for the synthesis of amines 9 and 11.

Finally, precursors $\mathbf{9}$ and $\mathbf{1 1}$ were subjected to the previously optimized conditions in the presence of piperidin-4-one 4A to afford the corresponding Pictet-Spengler products 12 and 13 in $52 \%$ yield with complete diastereoselectivity in both cases (Scheme 8).<smiles>NCCc1cc2ccccc2[nH]1</smiles>

9<smiles>NCCc1ccc[nH]1</smiles>

11

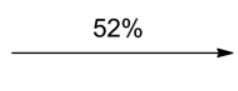

(1) $4 \mathrm{~A}, \mathrm{Ti}(\mathrm{OiPr})_{4}$ $21^{\circ} \mathrm{C}, 6 \mathrm{~h}$

(2) TFA (2.2 equiv.) $0-21^{\circ} \mathrm{C}, 6 \mathrm{~h}$

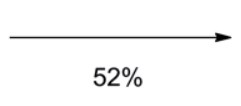

$52 \%$<smiles>[Al]C1CC2(CC([Al])N1)NCCc1[nH]c3ccccc3c12</smiles>

12

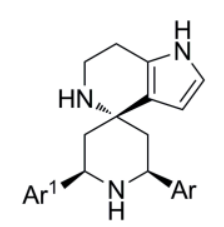

13

Scheme 8. Synthesis of spiro compounds $\mathbf{1 2}$ and $\mathbf{1 3 .}$

\section{Conclusions}

An enantio- and diastereoselective route for the synthesis of a new class of spirocyclic piperidine structures by means of a Mannich and Pictet-Spengler reaction sequence has been developed. Three new cis-2,6-disubstituted piperidin-4-one analogues containing fluorine functionalities were synthesized and

incorporated into the synthetic route. Finally, this methodology has been applied to the synthesis of a small library of compounds consisting of a total of 14 examples, all as single stereoisomers. Currently, the biological properties of these compounds are being evaluated in various assays.

\section{Experimental Section}

General Information: Full experimental details for the preparation of the compounds described herein, as well as details related to computational and mechanistic experiments, are provided in the Supporting Information. Reagents were obtained from commercial suppliers and used without purification. Standard syringe techniques were applied for the transfer of dry solvents and air- or moisture-sensitive reagents. TLC detection was performed with UV light and/or by charring at around $150{ }^{\circ} \mathrm{C}$ after dipping into a solution of either $2 \%$ anisaldehyde in ethanol $/ \mathrm{H}_{2} \mathrm{SO}_{4}$, $\left(\mathrm{NH}_{4}\right)_{6} \mathrm{Mo}_{7} \mathrm{O}_{24} \cdot 4 \mathrm{H}_{2} \mathrm{O}(25 \mathrm{~g} / \mathrm{L})$, or ninhydrin. Column or flash chromatography was carried out by using ACROS silica gel (0.035$0.070 \mathrm{~mm}, 60 \AA$ pore diameter). IR spectra were recorded with an IR-ATR Bruker TENSOR 27 spectrometer. High-resolution mass spectra were recorded with a JEOL AccuTOF (ESI) or a MAT900 (EI, CI and ESI) spectrometer. Optical rotations were determined with a Perkin-Elmer 241 polarimeter. NMR spectra were recorded at $298 \mathrm{~K}$ with a Varian Inova 400 (400 MHz), a Bruker Avance III $400 \mathrm{MHz}$, or a Bruker Avance III $500 \mathrm{MHz}$ spectrometer in the solvent indicated. Chemical shifts are given in parts per million (ppm) with respect to tetramethylsilane $(\delta=0.00 \mathrm{ppm})$ or $\mathrm{CHD}_{2} \mathrm{OD}(\delta=3.31 \mathrm{ppm})$ as internal standard for ${ }^{1} \mathrm{H}$ NMR and $\mathrm{CDCl}_{3}(\delta=77.16 \mathrm{ppm})$ or $\mathrm{CD}_{3} \mathrm{OD}$ ( $\delta=49.00 \mathrm{ppm})$ as internal standard for ${ }^{13} \mathrm{C}$ NMR. Coupling constants are reported as $J$ values in $\mathrm{Hz} .{ }^{1} \mathrm{H}$ NMR data are reported as follows: chemical shift (ppm), multiplicity ( $s=$ singlet, $d=$ doublet, $\mathrm{dd}=$ doublet of doublets, $\mathrm{dt}=$ doublet of triplets, $\mathrm{ddd}=$ doublet of doublet of doublets, $\mathrm{t}=$ triplet, $\mathrm{m}=$ multiplet, $\mathrm{br}$. = broad), coupling constants $(\mathrm{Hz})$ and integration. The compounds were fully characterized by ${ }^{1} \mathrm{H}$ and ${ }^{13} \mathrm{C}$ NMR spectra and $2 \mathrm{D}$ gDQCOSY, gHSQC, gHMBC and NOESY spectra.

(4S)-4-(3,4-Dimethoxyphenyl)-4-[(4-methoxyphenyl)amino]butan-2-one (1): 3,4-Dimethoxybenzaldehyde (10.5 g, $63.2 \mathrm{mmol})$, 4-anisidine $(7.78 \mathrm{~g}, 63.2 \mathrm{mmol})$ and L-proline $(1.5 \mathrm{~g}, 12.64 \mathrm{mmol})$ were added to a mixture of DMSO $(45 \mathrm{~mL})$ and acetone $(180 \mathrm{~mL})$. The resulting reaction mixture was stirred for $23 \mathrm{~h}$. The reaction was then quenched with potassium phosphate buffer $(0.5 \mathrm{M}, \mathrm{pH} 7$, $100 \mathrm{~mL})$. Subsequently, potassium phosphate buffer $(0.5 \mathrm{M}, \mathrm{pH} 7, \mathrm{a}$ total of $150 \mathrm{~mL}$ ) was added in portions. The reaction mixture was cooled to $0{ }^{\circ} \mathrm{C}$, and the product started to precipitate. After stirring for $20 \mathrm{~min}$, the suspension was filtered and the residue was washed with water $\left(0^{\circ} \mathrm{C}, 50 \mathrm{~mL}\right)$. The product was dried in vacuo. The product was obtained as an off-white powder $(19 \mathrm{~g})$ and recrystallized from EtOAc to give white crystals $(12.7 \mathrm{~g}, 38.5 \mathrm{mmol})$. Yield: $61 \%$. HPLC: ee $>99 \%$, Chiralpak AD-H $(250 \times 4.6 \mathrm{~mm})$, flow: $1.0 \mathrm{~mL} / \mathrm{min}$, heptane/propan-2-ol (80:20), retention time: 1: $18.7 \mathrm{~min}$, ent-1: 15.7 min. M.p. $147-151^{\circ} \mathrm{C} .[\alpha]_{\mathrm{D}}^{20}=+2.4\left(\mathrm{c}=0.41, \mathrm{CHCl}_{3}\right) .{ }^{1} \mathrm{H} \mathrm{NMR}$ $\left(400 \mathrm{MHz}, \mathrm{CDCl}_{3}\right): \delta=6.91-6.86(\mathrm{~m}, 2 \mathrm{H}), 6.83-6.77(\mathrm{~m}, 1 \mathrm{H}), 6.72-$ $6.66(\mathrm{~m}, 2 \mathrm{H}), 6.55-6.48(\mathrm{~m}, 2 \mathrm{H}), 4.69(\mathrm{t}, J=6.5 \mathrm{~Hz}, 1 \mathrm{H}), 3.84(\mathrm{~s}, 6$ H), $3.69(\mathrm{~s}, 3 \mathrm{H}), 2.88(\mathrm{~d}, J=6.5 \mathrm{~Hz}, 2 \mathrm{H}), 2.10(\mathrm{~s}, 3 \mathrm{H}) \mathrm{ppm} .{ }^{13} \mathrm{C}$ NMR $\left(101 \mathrm{MHz}, \mathrm{CDCl}_{3}\right): \delta=207.5,152.5,149.3,148.2,141.1,135.5,118.3$, 115.5, 114.8, 111.3, 109.6, 56.0, 55.9, 55.7, 55.3, 51.5, 30.9 ppm. FTIR: $\tilde{v}=3385,1708,1510,1253,1235,1139,1027,821 \mathrm{~cm}^{-1}$. HRMS (ESI): calcd. for $\mathrm{C}_{38} \mathrm{H}_{46} \mathrm{~N}_{2} \mathrm{O}_{8} \mathrm{Na}[\mathrm{M}+\mathrm{Na}]^{+}$352.15248; found 352.15248. 
(4S)-4-Amino-4-(3,4-dimethoxyphenyl)butan-2-one Hydrochloride (3): Aqueous $\mathrm{H}_{2} \mathrm{SO}_{4}(1 \mathrm{M}, 12.1 \mathrm{~mL}, 12.1 \mathrm{mmol})$ and $\mathrm{H}_{5} \mathrm{IO}_{6}$ $(2.87 \mathrm{~g}, 12.6 \mathrm{mmol})$ were added to a solution of (4S)-4-(3,4-dimethoxyphenyl)-4-(4-methoxyphenylamino)butan-2-one $(\mathbf{1} ; 4 \mathrm{~g}$, $12.1 \mathrm{mmol})$ in $\mathrm{MeCN} / \mathrm{H}_{2} \mathrm{O}(1: 1,120 \mathrm{~mL})$. The mixture was stirred at room temperature for $1.5 \mathrm{~h}$, washed with $\mathrm{CH}_{2} \mathrm{Cl}_{2}(3 \times 60 \mathrm{~mL})$, and the resulting aqueous phase was diluted with $\mathrm{CH}_{2} \mathrm{Cl}_{2}(60 \mathrm{~mL})$. The $\mathrm{pH}$ of the aqueous layer was brought to 9 by the addition of $5 \mathrm{M}$ aqueous $\mathrm{KOH}$ under vigorous stirring. The layers were separated, and the aqueous layer was extracted with $\mathrm{CH}_{2} \mathrm{Cl}_{2}(3 \times 60 \mathrm{~mL})$. The combined organic layers were dried with $\mathrm{Na}_{2} \mathrm{SO}_{4}$, and $\mathrm{HCl} / \mathrm{EtOAC}$ $(9.5 \mathrm{~mL})$ was added. The resulting mixture was concentrated until the product precipitated. The product was isolated by filtration and dried in vacuo to afford 3 ( $1.44 \mathrm{~g}, 5.54 \mathrm{mmol})$ as a pale-yellow solid. Yield: $46 \%$. ${ }^{1} \mathrm{H}$ NMR (400 MHz, CD $\left.{ }_{3} \mathrm{OD}\right): \delta=7.03(\mathrm{~d}, J=1.8 \mathrm{~Hz}, 1$ H), 7.00-6.96 (m, $2 \mathrm{H}), 4.64(\mathrm{t}, J=6.8 \mathrm{~Hz}, 1 \mathrm{H}), 3.87(\mathrm{~s}, 3 \mathrm{H}), 3.84$ (s, $3 \mathrm{H}), 3.20(\mathrm{~d}, J=6.8 \mathrm{~Hz}, 2 \mathrm{H}), 2.20(\mathrm{~s}, 3 \mathrm{H}) \mathrm{ppm} .{ }^{13} \mathrm{C} \mathrm{NMR}(101 \mathrm{MHz}$, $\left.\mathrm{CD}_{3} \mathrm{OD}\right): \delta=207.5,151.2,150.9,130.3,121.1,113.1,112.1,56.7,56.5$, 52.2, 47.6, 30.1 ppm. FTIR: $\tilde{v}=3395,2936,1709,1515,1264,1143$, $1018 \mathrm{~cm}^{-1}$. HRMS (ESI): calcd. for $\left[\mathrm{C}_{12} \mathrm{H}_{18} \mathrm{NO}_{3}+\mathrm{H}\right]^{+}$224.12867; found $224.13151(|\Delta|=12.69 \mathrm{ppm})$.

(3S)-4-(3,4-Dimethoxyphenyl)-4-[(E)-(4-fluorobenzylidene)amino]butan-2-one (5): Triethylamine $(0.44 \mathrm{~mL}, 3.18 \mathrm{mmol})$ and 4fluorobenzaldehyde $(0.34 \mathrm{~mL}, 3.18 \mathrm{mmol})$ were added to a solution of $3(1.65 \mathrm{~g}, 6.36 \mathrm{mmol})$ in dry 1,2-dichloroethane $(115 \mathrm{~mL})$. The mixture was concentrated in vacuo. Dry 1,2-dichloroethane $(110 \mathrm{~mL})$ was added to the residue, and the mixture was concentrated again in vacuo. Dry 1,2-dichloroethane $(110 \mathrm{~mL})$ and triethylamine $(0.44 \mathrm{~mL}, 3.18 \mathrm{mmol})$ were added to the resulting mixture, which was concentrated in vacuo. The mixture was dissolved in dry 1,2-dichloroethane $(113 \mathrm{~mL})$, and triethylamine $(0.44 \mathrm{~mL}$, $3.18 \mathrm{mmol})$ and 4-fluorobenzaldehyde $(0.03 \mathrm{~mL}, 0.32 \mathrm{mmol})$ were added. The resulting mixture was concentrated in vacuo to afford the crude imine. ${ }^{1} \mathrm{H}$ NMR ( $\left.400 \mathrm{MHz}, \mathrm{CD}_{3} \mathrm{OD}\right): \delta=8.33(\mathrm{~s}, 1 \mathrm{H}), 7.77-$ $7.70(\mathrm{~m}, 2 \mathrm{H}), 7.10-7.04(\mathrm{~m}, 2 \mathrm{H}), 6.98-6.93(\mathrm{~m}, 2 \mathrm{H}), 6.85-6.82(\mathrm{~m}$, $1 \mathrm{H}), 4.85(\mathrm{dd}, J=8.9,4.2 \mathrm{~Hz}, 1 \mathrm{H}), 3.90(\mathrm{~s}, 3 \mathrm{H}), 3.86(\mathrm{~s}, 3 \mathrm{H}), 3.21$ (dd, $J=16.3,8.9 \mathrm{~Hz}, 1 \mathrm{H}$ ), 2.89 (dd, $J=16.3,4.2 \mathrm{~Hz}, 1 \mathrm{H}$ ), 2.11 (s, 3 H) ppm.

General Procedure for the Synthesis of Compounds 4A-C: A mixture of $\mathbf{3}$ (1.00 equiv.), triethylamine (1.00 equiv.), the corresponding aldehyde (1.00 equiv.), L-proline ( 0.20 equiv.) and anhydrous $\mathrm{Na}_{2} \mathrm{SO}_{4}$ ( 0.28 equiv.) in $\mathrm{EtOH}$ was stirred at room temperature under an inert gas for 3-4 h. Then the reaction was quenched with $\mathrm{NH}_{4} \mathrm{Cl}(75 \mathrm{~mL})$, and the aqueous layer was extracted with EtOAc $(3 \times 200 \mathrm{~mL})$. The organic layers were combined and extracted with a solution $0.1 \mathrm{M} \mathrm{HCl}(3 \times 200 \mathrm{~mL})$. The combined aqueous layers were washed with EtOAc and neutralized with $1.0 \mathrm{M}$ aqueous sodium hydroxide to $\mathrm{pH} 7-8$. The aqueous layer was extracted with EtOAc $(3 \times 200 \mathrm{~mL})$, saturated brine solution was added, and the organic layers were dried with anhydrous $\mathrm{Na}_{2} \mathrm{SO}_{4}$, filtered and concentrated under reduced pressure to afford compounds $\mathbf{4 A - C}$.

(2S,6R)-2-(3,4-Dimethoxyphenyl)-6-(4-fluorophenyl)piperidin-4one (4A): According to the general procedure, the reaction of amino ketone hydrochloride $3(2.5 \mathrm{~g}, 9.63 \mathrm{mmol})$ and 4-fluorobenzaldehyde afforded $4 \mathbf{A}(2.4 \mathrm{~g}, 7.28 \mathrm{mmol})$ as an orange solid. Yield: $75 \% . R_{\mathrm{F}}=0.50$ (heptane/EtOAc, $\left.1: 1\right) .{ }^{1} \mathrm{H}$ NMR $(400 \mathrm{MHz}$, $\left.\mathrm{CDCl}_{3}\right): \delta=7.48-7.41(\mathrm{~m}, 2 \mathrm{H}), 7.08-7.02(\mathrm{~m}, 2 \mathrm{H}), 7.02-6.96(\mathrm{~m}, 2$ H), $6.85(\mathrm{~d}, J=8.1 \mathrm{~Hz}, 1 \mathrm{H}), 4.05(\mathrm{dd}, J=10.2,4.5 \mathrm{~Hz}, 1 \mathrm{H}), 4.01$ (dd, $J=10.9,3.7 \mathrm{~Hz}, 1 \mathrm{H}), 3.92(\mathrm{~s}, 3 \mathrm{H}), 3.88(\mathrm{~s}, 3 \mathrm{H}), 2.66-2.50(\mathrm{~m}, 4$ H) ppm. ${ }^{13} \mathrm{C} \mathrm{NMR}\left(101 \mathrm{MHz}, \mathrm{CDCl}_{3}\right): \delta=208.1,162.4(\mathrm{~d}, J=$ $246.2 \mathrm{~Hz}), 149.3,148.8,138.6(\mathrm{~d}, J=3.1 \mathrm{~Hz}), 135.4,128.3(\mathrm{~d}, J=$ $8.1 \mathrm{~Hz}, 2 \times), 118.8,115.7(\mathrm{~d}, J=21.3 \mathrm{~Hz}, 2 \times), 111.3,109.7,61.1$,
60.6, 56.1, 56.1, 50.7, 50.6 ppm. FTIR: $\tilde{v}=3305,1710,1509,1264$, $1232 \mathrm{~cm}^{-1}$. HRMS (ESI): calcd. for $\left[\mathrm{C}_{19} \mathrm{H}_{20} \mathrm{FNO}_{3}+\mathrm{H}\right]^{+} 330.15055$; found $330.15190(|\Delta|=4.11 \mathrm{ppm})$.

(2S,6R)-2-(3,4-Dimethoxyphenyl)-6-[4-(trifluoromethyl)phenyl]piperidin-4-one (4B): According to the general procedure, the reaction of amino ketone hydrochloride $3(2.5 \mathrm{~g}, 9.63 \mathrm{mmol})$ and 4-(trifluoromethyl)benzaldehyde afforded 4B $(1.4 \mathrm{~g}, 3.70 \mathrm{mmol})$ as an orange solid. Yield: $38 \% . R_{\mathrm{F}}=0.60$ (heptane/EtOAc, 1:1). ${ }^{1} \mathrm{H}$ NMR (400 MHz, $\left.\mathrm{CDCl}_{3}\right): \delta=7.66-7.56(\mathrm{~m}, 4 \mathrm{H}), 7.03-6.97(\mathrm{~m}, 2 \mathrm{H}), 6.85$ $(\mathrm{d}, J=8.1 \mathrm{~Hz}, 1 \mathrm{H}), 4.14(\mathrm{dd}, J=8.6,7.0 \mathrm{~Hz}, 1 \mathrm{H}), 4.03$ (dd, $J=11.0$, $3.6 \mathrm{~Hz}, 1 \mathrm{H}), 3.92(\mathrm{~s}, 3 \mathrm{H}), 3.88(\mathrm{~s}, 3 \mathrm{H}), 2.68-2.53(\mathrm{~m}, 4 \mathrm{H}) \mathrm{ppm} .{ }^{13} \mathrm{C}$ $\operatorname{NMR}\left(101 \mathrm{MHz}, \mathrm{CDCl}_{3}\right): \delta=207.5,149.4,148.9,146.7(\mathrm{q}, J=1.2 \mathrm{~Hz})$, 135.2, $130.3(q, J=32.5 \mathrm{~Hz}), 127.1(2 \times), 125.9(q, J=3.7 \mathrm{~Hz}, 2 \times)$, 122.7 ( $\mathrm{CF}_{3}$, indirect observation), 118.8, 111.3, 109.7, 61.1, 60.8, 56.1, 50.6, 50.3 ppm. HRMS (ESI): calcd. for $\left[\mathrm{C}_{20} \mathrm{H}_{21} \mathrm{~F}_{3} \mathrm{NO}_{3}+\mathrm{H}\right]^{+} 380.14735$; found $380.14778(|\Delta|=1.13 \mathrm{ppm})$.

(2S,6R)-2-(3,4-Dimethoxyphenyl)-6-[4-(pentafluoro- $\lambda^{6}$-sulfanyl)phenyl]piperidin-4-one (4C): According to the general procedure, the reaction of amino ketone hydrochloride $3(2.2 \mathrm{~g}, 8.61 \mathrm{mmol})$ and 4-(pentafluorosulfanyl)benzaldehyde afforded 4C $(1.07 \mathrm{~g}$, $2.45 \mathrm{mmol}$ ) as a yellow solid. Yield: $28 \% . R_{\mathrm{F}}=0.60$ (heptane/EtOAc, 1:1). ${ }^{1} \mathrm{H}$ NMR (400 MHz, $\left.\mathrm{CDCl}_{3}\right): \delta=7.79-7.74(\mathrm{~m}, 2 \mathrm{H}), 7.61-7.56$ $(\mathrm{m}, 2 \mathrm{H}), 7.03-6.96(\mathrm{~m}, 2 \mathrm{H}), 6.86(\mathrm{~d}, J=7.9 \mathrm{~Hz}, 1 \mathrm{H}), 4.17-4.12$ (dd, $J=8.3,6.5 \mathrm{~Hz}, 1 \mathrm{H}), 4.04(\mathrm{dd}, J=11.0,3.3 \mathrm{~Hz}, 1 \mathrm{H}), 3.92(\mathrm{~s}, 3 \mathrm{H})$, $3.88(\mathrm{~s}, 3 \mathrm{H}), 2.69-2.50(\mathrm{~m}, 4 \mathrm{H}) \mathrm{ppm} .{ }^{13} \mathrm{C} \mathrm{NMR}\left(101 \mathrm{MHz}, \mathrm{CDCl}_{3}\right)$ : $\delta=207.2,153.7$ (indirect observation), 149.4, 148.9, 146.6-146.5 (m), 135.1, $127.1(2 \times), 126.7-126.5(2 \times), 118.8,111.3,109.7,61.1$, 60.5, 56.1, 50.6, 50.2 ppm. FTIR: $\tilde{v}=1714,1517,829 \mathrm{~cm}^{-1}$. HRMS (ESI): calcd. for $\left[\mathrm{C}_{19} \mathrm{H}_{21} \mathrm{~F}_{5} \mathrm{NO}_{3} \mathrm{~S}+\mathrm{H}\right]^{+}$438.11623; found 438.11611 $(|\Delta|=0.27 \mathrm{ppm})$.

General Procedure for the Synthesis of Compounds 7Aa-Ca: A mixture of piperidin-4-one $\mathbf{4 A - C}$ (1.00 equiv.) and tryptamine (1.00 equiv. for the synthesis of $\mathbf{7 A a}$ and $\mathbf{7 C a}$ and 1.60 equiv. for the synthesis of $7 \mathrm{Ba}$ ) dissolved in $\mathrm{CH}_{2} \mathrm{Cl}_{2}$ in the presence of molecular sieves was stirred at $21{ }^{\circ} \mathrm{C}$ under an inert gas for the time indicated in each case. Then the solution was cooled to $0{ }^{\circ} \mathrm{C}$, TFA (2.2 equiv.) was added and the reaction mixture was warmed to $21{ }^{\circ} \mathrm{C}$ and stirred for the time indicated in each case. The reaction was quenched with a saturated $\mathrm{NaHCO}_{3}$ solution, and the aqueous layer was extracted with $\mathrm{CH}_{2} \mathrm{Cl}_{2}(3 \times)$. The combined organic layers were washed with brine, dried with $\mathrm{Na}_{2} \mathrm{SO}_{4}$, filtered and concentrated in vacuo.

(2S,4S,6R)-2-(3,4-Dimethoxyphenyl)-6-(4-fluorophenyl)$2^{\prime}, 3^{\prime}, 4^{\prime}, 9^{\prime}$-tetrahydrospiro[piperidine-4, 1'-pyrido[3,4-b]indole] (7Aa): According to the general procedure, the reaction mixture of piperidin-4-one 4A $(51.5 \mathrm{mg}, 0.16 \mathrm{mmol})$ was stirred in $\mathrm{CH}_{2} \mathrm{Cl}_{2}$ $(2.5 \mathrm{~mL})$ overnight to form the imine. TFA $(27 \mu \mathrm{L}, 0.34 \mathrm{mmol})$ in $\mathrm{CH}_{2} \mathrm{Cl}_{2}(0.14 \mathrm{~mL})$ was added, and the mixture was stirred for $48 \mathrm{~h}$. The crude mixture was purified by column chromatography [heptane/EtOAc (4:1) $\rightarrow$ EtOAc] and ion-exchange column chromatography (ISOLUTE SCX-2) to afford compound 7Aa (38.5 mg, $0.08 \mathrm{mmol}$ ) as a yellow solid. Yield: $52 \% . R_{\mathrm{F}}=0.43$ (EtOAc). ${ }^{1} \mathrm{H}$ NMR $(500 \mathrm{MHz}$, $\left.\mathrm{CDCl}_{3}\right): \delta=7.86$ (br. s, $\left.1 \mathrm{H}\right), 7.49-7.44(\mathrm{~m}, 3 \mathrm{H}), 7.29(\mathrm{~d}, J=8.0 \mathrm{~Hz}$, $1 \mathrm{H}), 7.13$ (ddd, $J=8.1,7.1,1.3 \mathrm{~Hz}, 1 \mathrm{H}), 7.10-7.06(\mathrm{~m}, 1 \mathrm{H}), 7.06-$ $6.98(\mathrm{~m}, 4 \mathrm{H}), 6.83(\mathrm{~d}, J=8.2 \mathrm{~Hz}, 1 \mathrm{H}), 4.50-4.43(\mathrm{~m}, 1 \mathrm{H}), 4.40(\mathrm{dd}$, $J=10.9,3.1 \mathrm{~Hz}, 1 \mathrm{H}), 3.92(\mathrm{~s}, 3 \mathrm{H}), 3.86(\mathrm{~s}, 3 \mathrm{H}), 3.26(\mathrm{t}, J=5.7 \mathrm{~Hz}$, $2 \mathrm{H}), 2.75(\mathrm{t}, J=5.7 \mathrm{~Hz}, 2 \mathrm{H}), 2.08-1.93(\mathrm{~m}, 4 \mathrm{H}) \mathrm{ppm} .{ }^{13} \mathrm{C}$ NMR $\left(126 \mathrm{MHz}, \mathrm{CDCl}_{3}\right): \delta=162.1(\mathrm{~d}, J=244.7 \mathrm{~Hz}), 149.1,148.4,140.5$, 139.4, 137.3, 135.6, $128.4(\mathrm{~d}, J=7.9 \mathrm{~Hz}, 2 \times), 127.6,121.9,119.5$, 119.0, 118.3, $115.4(\mathrm{~d}, J=21.1 \mathrm{~Hz}, 2 \times), 111.3,110.9,110.2,108.9$, 56.6, 56.3, 56.1, 56.1, 53.3, 45.1, 45.1, 39.4, 23.3 ppm. FTIR: $\tilde{v}=3364$, 2933, 2835, 1603, 1507, 1223, 1136, 1025, $804 \mathrm{~cm}^{-1}$. HRMS (ESI): 
calcd. for $\left[\mathrm{C}_{29} \mathrm{H}_{30} \mathrm{FN}_{3} \mathrm{O}_{2}+\mathrm{H}\right]^{+}$472.23985; found $472.24003(|\Delta|=$ $0.4 \mathrm{ppm})$.

(2S,4S,6R)-2-(3,4-Dimethoxyphenyl)-6-[4-(trifluoromethyl)phenyl]-2', 3', $4^{\prime}, 9^{\prime}$-tetrahydrospiro[piperidine-4, 1'-pyrido[3,4-b]indole] (7Ba): According to the general procedure, the reaction mixture of piperidin-4-one 4B (100 $\mathrm{mg}, 0.26 \mathrm{mmol}$ ) was stirred, in the presence of $4 \AA$ molecular sieves, in $\mathrm{CH}_{2} \mathrm{Cl}_{2}(5 \mathrm{~mL})$ for $5 \mathrm{~h}$ to form the imine. TFA $(44 \mu \mathrm{L}, 0.57 \mathrm{mmol})$ in $\mathrm{CH}_{2} \mathrm{Cl}_{2}(0.25 \mathrm{~mL})$ was added, and the mixture was stirred for $24 \mathrm{~h}$. The crude product was purified by two column chromatographic procedures [heptane/ EtOAc (3:1) $\rightarrow$ EtOAc/MeOH (10:1) and heptane/EtOAc (2:3) $\rightarrow$ EtOAc/MeOH (10:1)] to afford compound 7Ba (56.6 mg, $0.11 \mathrm{mmol})$. Yield: $41 \% . R_{\mathrm{F}}=0.22$ (heptane/EtOAc, 2:3). ${ }^{1} \mathrm{H}$ NMR $(400 \mathrm{MHz}$, $\mathrm{CDCl}_{3}$ ): $\delta=7.84$ (br. s, $1 \mathrm{H}$ ), 7.67-7.55 (m, $\left.4 \mathrm{H}\right), 7.47(\mathrm{~d}, J=7.7 \mathrm{~Hz}$, $1 \mathrm{H}), 7.27(\mathrm{dt}, J=8.0,0.9 \mathrm{~Hz}, 1 \mathrm{H}), 7.13(\mathrm{ddd}, J=8.1,7.1,1.3 \mathrm{~Hz}, 1$ H), 7.10-7.01 (m, 3 H), $6.84(\mathrm{~d}, J=8.1 \mathrm{~Hz}, 1 \mathrm{H}), 4.54(\mathrm{dd}, J=10.5$, $3.5 \mathrm{~Hz}, 1 \mathrm{H}), 4.42(\mathrm{dd}, J=10.4,3.4 \mathrm{~Hz}, 1 \mathrm{H}), 3.92(\mathrm{~s}, 3 \mathrm{H}), 3.87(\mathrm{~s}, 3$ $\mathrm{H})$, 3.34-3.20 (m, $2 \mathrm{H}), 2.75(\mathrm{t}, J=5.7 \mathrm{~Hz}, 2 \mathrm{H}), 2.08-1.90(\mathrm{~m}, 4 \mathrm{H})$ ppm. ${ }^{13} \mathrm{C}$ NMR $\left(101 \mathrm{MHz}, \mathrm{CDCl}_{3}\right): \delta=149.1,149.0(\mathrm{q}, J=1.0 \mathrm{~Hz})$, 148.4, 139.2, 137.3, 135.6, $129.6(q, J=32.3 \mathrm{~Hz}), 127.5,127.2(2 \times)$, $125.6(\mathrm{q}, J=3.7 \mathrm{~Hz}, 2 \times), 124.3\left(\mathrm{q}, J=272.2 \mathrm{~Hz}, \mathrm{CF}_{3}\right), 122.0,119.6$, 118.9, 118.4, 111.3, 110.9, 110.1, 109.0, 56.6, 56.4, $56.1(2 \times), 53.2$, 45.2, 45.0, 39.4, 23.3 ppm. FTIR: $\tilde{v}=3367,2931,2838,1618,1516$, $1261,1118,1017,806 \mathrm{~cm}^{-1}$. HRMS (ESI): calcd. for $\left[\mathrm{C}_{30} \mathrm{H}_{30} \mathrm{~F}_{3} \mathrm{~N}_{3} \mathrm{O}_{2}+\right.$ $\mathrm{H}]^{+}$522.23708; found $522.23684(|\Delta|=0.5 \mathrm{ppm})$.

(2S,4S,6R)-2-(3,4-Dimethoxyphenyl)-6-[4-(pentafluoro- $\lambda^{6}$ sulfanyl)phenyl]-2', $3^{\prime}, 4^{\prime}, 9^{\prime}$-tetrahydrospiro[piperidine-4, $1^{\prime}$-pyrido[3,4-b]indole] (7Ca): According to the general procedure, the reaction mixture of piperidin-4-one $4 \mathrm{C}(40 \mathrm{mg}, 0.09 \mathrm{mmol})$ was stirred, in the presence of $4 \AA$ molecular sieves, in $\mathrm{CH}_{2} \mathrm{Cl}_{2}(1.5 \mathrm{~mL})$ for $5 \mathrm{~h}$ to form the imine. TFA ( $20 \mu \mathrm{L}, 0.20 \mathrm{mmol})$ was added, and the mixture was stirred overnight. The crude product was purified by column chromatography [heptane/EtOAc (4:1) $\rightarrow$ EtOAc] to afford compound 7Ca (24.4 mg, $0.042 \mathrm{mmol})$. Yield: $47 \%$. $R_{\mathrm{F}}=0.34$ (heptane/EtOAc, 2:3). ${ }^{1} \mathrm{H}$ NMR $\left(400 \mathrm{MHz}, \mathrm{CDCl}_{3}\right): \delta=7.89(\mathrm{~s}, 1 \mathrm{H})$, 7.75-7.69 (m, $2 \mathrm{H}), 7.62-7.57(\mathrm{~m}, 2 \mathrm{H}), 7.48(\mathrm{~d}, J=7.7 \mathrm{~Hz}, 1 \mathrm{H}), 7.27$ $(\mathrm{d}, J=7.4 \mathrm{~Hz}, 1 \mathrm{H}), 7.14(\mathrm{t}, J=7.5 \mathrm{~Hz}, 1 \mathrm{H}), 7.11-7.01(\mathrm{~m}, 3 \mathrm{H}), 6.85$ $(\mathrm{d}, J=8.1 \mathrm{~Hz}, 1 \mathrm{H}), 4.55(\mathrm{dd}, J=10.3,2.9 \mathrm{~Hz}, 1 \mathrm{H}), 4.43(\mathrm{dd}, J=$ 10.6, $2.7 \mathrm{~Hz}, 1 \mathrm{H}), 3.92(\mathrm{~s}, 3 \mathrm{H}), 3.87(\mathrm{~s}, 3 \mathrm{H}), 3.37-3.17(\mathrm{~m}, 2 \mathrm{H}), 2.76$ $(\mathrm{t}, J=5.5 \mathrm{~Hz}, 2 \mathrm{H}), 2.12-1.91(\mathrm{~m}, 4 \mathrm{H}), 1.86$ (br. s, $1 \mathrm{H}) \mathrm{ppm} .{ }^{13} \mathrm{C}$ NMR (101 MHz, $\left.\mathrm{CDCl}_{3}\right): \delta=152.9$ (quint, $J=17.1 \mathrm{~Hz}$ ), 149.1, 148.8, 148.4, 139.1, 137.1, 135.6, 127.5, $127.1(2 \times), 126.3$ (quint, $J=4.6 \mathrm{~Hz}$, $2 \times), 122.0,119.5,118.9,118.4,111.3,110.9,110.1,109.0,56.3(2 \times)$, 56.1, 56.1, 53.2, 45.1, 44.8, 39.4, 23.2 ppm. FTIR: $\tilde{v}=3373,2934$, $2838,1592,1515,1232,1138,1027,840 \mathrm{~cm}^{-1}$. HRMS (ESI): calcd. for $\left[\mathrm{C}_{29} \mathrm{H}_{31} \mathrm{~F}_{5} \mathrm{~N}_{3} \mathrm{O}_{2} \mathrm{~S}+\mathrm{H}\right]^{+}$580.20571; found 580.20471 (| $\left.\Delta \mid=1.73 \mathrm{ppm}\right)$.

General Procedure for the Synthesis of Compounds 7Ab-Cb: $\mathrm{A}$ solution of $\mathrm{Ti}(\mathrm{OiPr})_{4}(1.30$ equiv. $)$ in dry THF $(0.5 \mathrm{~mL})$ was added to a mixture of piperidin-4-one $\mathbf{4 A - C}$ (1.00 equiv.) and 6-methoxytryptamine (1.20 equiv.) in dry THF $(2 \mathrm{~mL})$ at $21{ }^{\circ} \mathrm{C}$ under argon. After $6 \mathrm{~h}$, TFA (2.20 equiv.) dissolved in dry THF $(0.5 \mathrm{~mL})$ was added at $0{ }^{\circ} \mathrm{C}$, and the reaction mixture was warmed to $21{ }^{\circ} \mathrm{C}$ and stirred for $19-24 \mathrm{~h}$. The reaction was quenched with a saturated $\mathrm{NaHCO}_{3}$ solution and the mixture diluted with EtOAc. The layers were separated, and the aqueous phase was extracted with EtOAc $(3 \times)$. The combined organic layers were washed with brine, dried with $\mathrm{Na}_{2} \mathrm{SO}_{4}$, filtered and concentrated in vacuo. The crude product was purified by column chromatography [heptane/EtOAc (2:1) $\rightarrow$ EtOAc/MeOH (10:1)]. The dried product was dissolved in $\mathrm{CH}_{2} \mathrm{Cl}_{2}(5 \mathrm{~mL})$ and washed with aqueous $\mathrm{NH}_{4} \mathrm{OH}(5 \mathrm{~mL})$. The aqueous phase was extracted with $\mathrm{CH}_{2} \mathrm{Cl}_{2}(3 \times 5 \mathrm{~mL})$, and the combined organic layers were washed with brine, dried with $\mathrm{Na}_{2} \mathrm{SO}_{4}$, filtered and dried in vacuo to afford compounds $\mathbf{7 A b}-\mathbf{C b}$.
(2S,4S,6R)-2-(3,4-Dimethoxyphenyl)-6-(4-fluorophenyl)-7'-methoxy-2', 3', $4^{\prime}, 9^{\prime}$-tetrahydrospiro[piperidine-4, 1'-pyrido[3,4-b]indole] (7Ab): According to the general procedure, the reaction of piperidin-4-one 4A (50 mg, $0.152 \mathrm{mmol}$ ) afforded 7Ab $(41.5 \mathrm{mg}$, $0.083 \mathrm{mmol}$ ). Yield (BORSM): $74 \% . R_{\mathrm{F}}=0.30$ (heptane/EtOAc/Et ${ }_{3} \mathrm{~N}$, 4:4:1). ${ }^{1} \mathrm{H}$ NMR (400 MHz, $\left.\mathrm{CDCl}_{3}\right): \delta=7.79$ (br. s, $\left.1 \mathrm{H}\right), 7.48-7.44(\mathrm{~m}$, $2 \mathrm{H}), 7.33(\mathrm{~d}, J=8.6 \mathrm{~Hz}, 1 \mathrm{H}), 7.05(\mathrm{~d}, J=1.9 \mathrm{~Hz}, 1 \mathrm{H}), 7.03-6.98(\mathrm{~m}$, $3 \mathrm{H}), 6.82(\mathrm{~d}, J=8.3 \mathrm{~Hz}, 1 \mathrm{H}), 6.80(\mathrm{~d}, J=2.2 \mathrm{~Hz}, 1 \mathrm{H}), 6.74(\mathrm{dd}, J=$ 8.6, $2.2 \mathrm{~Hz}, 1 \mathrm{H}), 4.44(\mathrm{dd}, J=9.1,4.9 \mathrm{~Hz}, 1 \mathrm{H}), 4.39$ (dd, $J=11.0$, $2.9 \mathrm{~Hz}, 1 \mathrm{H}), 3.91(\mathrm{~s}, 3 \mathrm{H}), 3.86(\mathrm{~s}, 3 \mathrm{H}), 3.81(\mathrm{~s}, 3 \mathrm{H}), 3.24(\mathrm{t}, J=$ $5.7 \mathrm{~Hz}, 2 \mathrm{H}), 2.70(\mathrm{t}, J=5.7 \mathrm{~Hz}, 2 \mathrm{H}), 2.06-1.92(\mathrm{~m}, 4 \mathrm{H}), 1.72$ (br. $\mathrm{s}$, $2 \mathrm{H}) \mathrm{ppm} .{ }^{13} \mathrm{C}$ NMR $\left(126 \mathrm{MHz}, \mathrm{CDCl}_{3}\right): \delta=162.1(\mathrm{~d}, J=245.0 \mathrm{~Hz})$, $156.4,149.1,148.3,140.5,138.2,137.3,136.4,128.4(d, J=7.9 \mathrm{~Hz}$, $2 \times), 122.0,118.9,118.8,115.4(\mathrm{~d}, J=21.2 \mathrm{~Hz}, 2 \times), 111.2,110.1$, 108.9, 108.7, 95.1, 56.6, 56.3, 56.1 (2 (x), 55.9, 53.2, 45.1, 45.0, 39.4, 23.3 ppm. FTIR: $\tilde{v}=3366,2931,2835,1628,1507,1223,1153,1025$, $764 \mathrm{~cm}^{-1}$. HRMS (ESI): calcd. for $\left[\mathrm{C}_{30} \mathrm{H}_{32} \mathrm{FN}_{3} \mathrm{O}_{3}+\mathrm{H}\right]^{+}$502.25093; found $502.25059(|\Delta|=0.7 \mathrm{ppm})$.

(2S,4S,6R)-2-(3,4-Dimethoxyphenyl)-7'-methoxy-6-[4-(trifluoromethyl)phenyl]-2', $3^{\prime}, 4^{\prime}, 9^{\prime}$-tetrahydrospiro[piperidine-4, $\mathbf{1}^{\prime}$-pyrido[3,4-b]indole] (7Bb): According to the general procedure, the reaction of piperidin-4-one $\mathbf{4 B}(50 \mathrm{mg}, 0.132 \mathrm{mmol})$ afforded $\mathbf{7 B b}$ (56.0 mg, $0.102 \mathrm{mmol}$ ). Yield: $77 \% . R_{\mathrm{F}}=0.32$ (heptane/EtOAc/Et ${ }_{3} \mathrm{~N}$, 4:4:1). ${ }^{1} \mathrm{H}$ NMR (500 MHz, $\mathrm{CDCl}_{3}$ ): $\delta=7.69$ (br. s, $\left.1 \mathrm{H}\right), 7.64-7.55(\mathrm{~m}$, $4 \mathrm{H}), 7.34(\mathrm{~d}, J=8.6 \mathrm{~Hz}, 1 \mathrm{H}), 7.06-7.01(\mathrm{~m}, 2 \mathrm{H}), 6.84(\mathrm{~d}, J=8.2 \mathrm{~Hz}$, $1 \mathrm{H}), 6.80(\mathrm{~d}, J=2.2 \mathrm{~Hz}, 1 \mathrm{H}), 6.75(\mathrm{dd}, J=8.6,2.2 \mathrm{~Hz}, 1 \mathrm{H}), 4.53$ (dd, $J=11.1,2.3 \mathrm{~Hz}, 1 \mathrm{H}), 4.41$ (dd, $J=10.3,3.5 \mathrm{~Hz}, 1 \mathrm{H}), 3.92(\mathrm{~s}, 3$ H), $3.87(\mathrm{~s}, 3 \mathrm{H}), 3.81(\mathrm{~s}, 3 \mathrm{H}), 3.28-3.22(\mathrm{~m}, 2 \mathrm{H}), 2.71(\mathrm{t}, J=5.6 \mathrm{~Hz}$, $2 \mathrm{H}), 2.05-1.89(\mathrm{~m}, 4 \mathrm{H}), 1.62$ (br. s, $2 \mathrm{H}) \mathrm{ppm} .{ }^{13} \mathrm{C}$ NMR $(101 \mathrm{MHz}$, $\left.\mathrm{CDCl}_{3}\right): \delta=156.4,149.1,149.0,148.4,138.1,137.3,136.4,129.6$ (q, $J=32.3 \mathrm{~Hz}), 127.2(2 \times), 125.5(\mathrm{q}, J=3.7 \mathrm{~Hz}, 2 \times), 124.3(\mathrm{q}, J=$ $\left.272.0 \mathrm{~Hz}, \mathrm{CF}_{3}\right), 122.0,118.9,118.8,111.3,110.2,108.8,108.7,95.2$, 56.6, 56.4, $56.1(2 \times), 55.9,53.2,45.1,44.9,39.4,23.3$ ppm. FTIR: $\tilde{v}=$ 3369, 2926, 2835, 1619, 1515, 1260, 1097, 1066, $797 \mathrm{~cm}^{-1}$. HRMS (ESI): calcd. for $\left[\mathrm{C}_{31} \mathrm{H}_{32} \mathrm{~F}_{3} \mathrm{~N}_{3} \mathrm{O}_{3}+\mathrm{H}\right]^{+} 552.24737$; found 552.24740 $(|\Delta|=0.1 \mathrm{ppm})$.

(2S,4S,6R)-2-(3,4-Dimethoxyphenyl)-7'-methoxy-6-[4-(pentafluoro- $\lambda^{6}$-sulfanyl)phenyl]-2', $3^{\prime}, 4^{\prime}, 9^{\prime}$-tetrahydrospiro[piperidine-4, $\mathbf{1}^{\prime}$-pyrido[3,4-b]indole] (7Cb): According to the general procedure, the reaction of piperidin-4-one $4 \mathrm{C}(50 \mathrm{mg}, 0.114 \mathrm{mmol})$ afforded $\mathbf{7 C b}(18.1 \mathrm{mg}, 0.030 \mathrm{mmol})$. In this case, after applying the general procedure, the crude product was purified by a second column chromatography [heptane/EtOAc (2:1) $\rightarrow$ EtOAc/MeOH (10:1)] and ion-exchange column chromatography (ISOLUTE SCX-2). The dried product was dissolved again in $\mathrm{CH}_{2} \mathrm{Cl}_{2}(5 \mathrm{~mL})$ and washed with aqueous $\mathrm{NH}_{4} \mathrm{OH}(5 \mathrm{~mL})$. The combined aqueous layers were extracted with $\mathrm{CH}_{2} \mathrm{Cl}_{2}(3 \times 5 \mathrm{~mL})$, and the organic layers were washed with brine, dried with $\mathrm{Na}_{2} \mathrm{SO}_{4}$, filtered and dried in vacuo. Yield (BORSM): $56 \% . R_{\mathrm{F}}=0.28$ (heptane/EtOAc/Et $\left.{ }_{3} \mathrm{~N}, 4: 4: 1\right) .{ }^{1} \mathrm{H}$ NMR $\left(400 \mathrm{MHz}, \mathrm{CDCl}_{3}\right): \delta=7.73-7.70(\mathrm{~m}, 2 \mathrm{H}), 7.68$ (br. s, $\left.1 \mathrm{H}\right), 7.61-7.57$ $(\mathrm{m}, 2 \mathrm{H}), 7.34(\mathrm{~d}, J=8.6 \mathrm{~Hz}, 1 \mathrm{H}), 7.04(\mathrm{~d}, J=2.0 \mathrm{~Hz}, 1 \mathrm{H}), 7.02(\mathrm{dd}$, $J=8.2,2.0 \mathrm{~Hz}, 1 \mathrm{H}), 6.84(\mathrm{~d}, J=8.2 \mathrm{~Hz}, 1 \mathrm{H}), 6.79(\mathrm{~d}, J=2.2 \mathrm{~Hz}, 1$ H), $6.75(\mathrm{dd}, J=8.6,2.2 \mathrm{~Hz}, 1 \mathrm{H}), 4.53(\mathrm{dd}, J=11.1,2.2 \mathrm{~Hz}, 1 \mathrm{H})$, 4.41 (dd, J = 10.4, $3.5 \mathrm{~Hz}, 1 \mathrm{H}), 3.92(\mathrm{~s}, 3 \mathrm{H}), 3.87(\mathrm{~s}, 3 \mathrm{H}), 3.81$ (s, 3 H), 3.28-3.21 (m, $2 \mathrm{H}), 2.71(\mathrm{t}, J=5.7 \mathrm{~Hz}, 2 \mathrm{H}), 2.04-1.87(\mathrm{~m}, 4 \mathrm{H})$, 1.62 (br. s, $2 \mathrm{H}$ ) ppm. ${ }^{13} \mathrm{C}$ NMR $\left(126 \mathrm{MHz}, \mathrm{CDCl}_{3}\right): \delta=156.5,152.9$ (quint, $J=17.6 \mathrm{~Hz}$ ), 149.1, 148.8, 148.5, 137.9, 137.1, 136.4, 127.1 $(2 \times), 126.3$ (quint, $J=4.4 \mathrm{~Hz}, 2 \times), 122.0,118.9,118.9,111.3,110.1$, 108.9, 108.8, 95.2, $56.3(2 \times), 56.1,56.1,55.9,53.2,45.1,44.8,39.4$, 23.3 ppm. FTIR: $\tilde{v}=3371,2938,2837,1629,1516,1262,1154,1027$, 823, $729 \mathrm{~cm}^{-1}$. HRMS (ESI): calcd. for $\left[\mathrm{C}_{30} \mathrm{H}_{32} \mathrm{~F}_{5} \mathrm{~N}_{3} \mathrm{O}_{3} \mathrm{~S}+\mathrm{H}\right]^{+}$ 610.21561; found $610.21628(|\Delta|=1.1 \mathrm{ppm})$. 
(2S,4S,6R)-2-(3,4-Dimethoxyphenyl)-6-(4-fluorophenyl)$2^{\prime}, 3^{\prime}, 4^{\prime}, 9^{\prime}$-tetrahydrospiro[piperidine-4, 1'-pyrido[3,4-b]indol]-6'ol (7Ac): $\mathrm{Et}_{3} \mathrm{~N}(25 \mu \mathrm{L}, 0.182 \mathrm{mmol})$ dissolved in dry THF $(0.25 \mathrm{~mL})$ and $\mathrm{Ti}(\mathrm{OiPr})_{4}(58 \mu \mathrm{L}, 0.197 \mathrm{mmol})$ dissolved in dry THF $(0.25 \mathrm{~mL})$ were added to a mixture of $\mathbf{4 A}(50 \mathrm{mg}, 0.152 \mathrm{mmol})$ and 5-hydroxytryptamine hydrochloride $(38.7 \mathrm{mg}, 0.182 \mathrm{mmol}$ ) dissolved in dry THF $(0.5 \mathrm{~mL})$. After $30 \mathrm{~min}$, additional $\mathrm{Et}_{3} \mathrm{~N}(25 \mu \mathrm{L}, 0.182 \mathrm{mmol})$ and THF $(16.5 \mathrm{~mL})$ were added. After $4.5 \mathrm{~h}$, TFA $(52 \mu \mathrm{L}, 0.668 \mathrm{mmol})$ dissolved in dry THF $(0.5 \mathrm{~mL})$ was added at $0{ }^{\circ} \mathrm{C}$, and the reaction mixture was warmed to $21{ }^{\circ} \mathrm{C}$ and stirred for $21 \mathrm{~h}$. The reaction was quenched with an aqueous saturated $\mathrm{NaHCO}_{3}$ solution and the mixture diluted with EtOAc. The organic and aqueous phases were separated, and the aqueous phase was extracted with EtOAc $(4 \times)$. The combined organic layers were washed with brine, dried with $\mathrm{Na}_{2} \mathrm{SO}_{4}$, filtered and dried in vacuo. The crude product was dissolved in dry THF (2 mL), and 5-hydroxytryptamine hydrochloride (15.5 mg, $0.073 \mathrm{mmol}), \mathrm{Et}_{3} \mathrm{~N}(10 \mu \mathrm{L}, 0.073 \mathrm{mmol})$ in dry THF $(0.5 \mathrm{~mL})$ and $\mathrm{Ti}(\mathrm{OiPr})_{4}(23.2 \mu \mathrm{L}, 0.079 \mathrm{mmol})$ were added. After $3 \mathrm{~h}$, TFA $\left(10.4 \mu \mathrm{L}, 0.134 \mathrm{mmol}\right.$ ) was added at $0{ }^{\circ} \mathrm{C}$, and the reaction mixture was warmed to $21{ }^{\circ} \mathrm{C}$ and stirred for $20.5 \mathrm{~h}$. The reaction was quenched with an aqueous saturated $\mathrm{NaHCO}_{3}$ solution and diluted with EtOAc. The organic and aqueous phases were separated, and the aqueous phase was extracted with EtOAc $(4 \times)$. The combined organic layers were washed with brine, dried with $\mathrm{Na}_{2} \mathrm{SO}_{4}$, filtered and dried in vacuo. The crude product was purified by column chromatography [EtOAc $\rightarrow$ EtOAc/MeOH (10:1)]. The dried product was dissolved in $\mathrm{CH}_{2} \mathrm{Cl}_{2}(5 \mathrm{~mL})$ and washed with aqueous $\mathrm{NH}_{4} \mathrm{OH}(2 \times$ $5 \mathrm{~mL}$ ). The combined aqueous layers were extracted with $\mathrm{CH}_{2} \mathrm{Cl}_{2}$ $(3 \times 10 \mathrm{~mL})$, and the combined organic layers were washed with brine, dried with $\mathrm{Na}_{2} \mathrm{SO}_{4}$, filtered and dried in vacuo to afford $7 \mathrm{Ac}$ (37.0 mg, $0.076 \mathrm{mmol})$ as a yellow solid. Yield (BORSM): $80 \% . R_{\mathrm{F}}=$ $0.32\left(\mathrm{EtOAc}_{\mathrm{Et}} \mathrm{N}_{3} \mathrm{~N}, 8: 1\right) .{ }^{1} \mathrm{H} \mathrm{NMR}\left(500 \mathrm{MHz}, \mathrm{CDCl}_{3}\right): \delta=7.81$ (br. s, 1 $\mathrm{H}), 7.45(\mathrm{~m}, 2 \mathrm{H}), 7.09(\mathrm{~d}, J=8.6 \mathrm{~Hz}, 1 \mathrm{H}), 7.05(\mathrm{~d}, J=2.0 \mathrm{~Hz}, 1 \mathrm{H})$, 7.03-6.96 (m, $3 \mathrm{H}), 6.84(\mathrm{~d}, J=2.4 \mathrm{~Hz}, 1 \mathrm{H}), 6.81(\mathrm{~d}, J=8.2 \mathrm{~Hz}, 1 \mathrm{H})$, $6.67(\mathrm{dd}, J=8.6,2.4 \mathrm{~Hz}, 1 \mathrm{H}), 4.44(\mathrm{dd}, J=10.4,3.6 \mathrm{~Hz}, 1 \mathrm{H}), 4.39$ $(\mathrm{dd}, J=11.1,2.6 \mathrm{~Hz}, 1 \mathrm{H}), 3.87(\mathrm{~s}, 3 \mathrm{H}), 3.85(\mathrm{~s}, 3 \mathrm{H}), 3.22(\mathrm{t}, J=$ $5.7 \mathrm{~Hz}, 2 \mathrm{H}), 2.63(\mathrm{t}, J=5.7 \mathrm{~Hz}, 2 \mathrm{H}), 2.10-1.93(\mathrm{~m}, 4 \mathrm{H}) \mathrm{ppm} .{ }^{13} \mathrm{C}$ NMR (101 MHz, CDCl $): \delta=162.1(\mathrm{~d}, J=245.2 \mathrm{~Hz}), 149.6,149.1$, $148.4,140.6,140.2(\mathrm{~d}, J=2.9 \mathrm{~Hz}), 137.1,130.9,128.5(\mathrm{~d}, J=7.9 \mathrm{~Hz}$, $2 \times), 128.3,119.0,115.4(\mathrm{~d}, J=21.2 \mathrm{~Hz}, 2 \times), 111.5,111.5,111.3$, $110.2,108.4,103.4,56.7,56.4,56.1,56.1,53.4,44.8(2 \times), 39.3$, 23.2 ppm. FTIR: $\tilde{v}=3367,2931,2838,1591,1515,1261,1118,1016$, $800 \mathrm{~cm}^{-1}$. HRMS (ESI): calcd. for $\left[\mathrm{C}_{29} \mathrm{H}_{30} \mathrm{FN}_{3} \mathrm{O}_{3}+\mathrm{H}\right]^{+}$488.23454; found $488.23494(|\Delta|=0.8 \mathrm{ppm})$.

(2S,4S,6R)-2-(3,4-Dimethoxyphenyl)-6-[4-(trifluoromethyl)phenyl]-2', 3', 4', $9^{\prime}$-tetrahydrospiro[piperidine-4, 1'-pyrido[3,4-b]indol]-6'-ol (7BC): $\mathrm{Et}_{3} \mathrm{~N}(22 \mu \mathrm{L}, 0.158 \mathrm{mmol})$ dissolved in dry THF $(0.50 \mathrm{~mL})$ and $\mathrm{Ti}(\mathrm{O} i \operatorname{Pr})_{4}(50 \mu \mathrm{L}, 0.171 \mathrm{mmol})$ dissolved in dry THF $(0.50 \mathrm{~mL})$ were added to a mixture of $\mathbf{4 B}(50 \mathrm{mg}, 0.132 \mathrm{mmol})$ and 5-hydroxytryptamine hydrochloride $(33.6 \mathrm{mg}, 0.158 \mathrm{mmol})$ dissolved in dry THF $(2 \mathrm{~mL})$. After $7 \mathrm{~h}$, TFA $(22 \mu \mathrm{L}, 0.290 \mathrm{mmol})$ dissolved in dry THF $(0.5 \mathrm{~mL})$ was added at $0{ }^{\circ} \mathrm{C}$, and the reaction mixture was warmed to $21{ }^{\circ} \mathrm{C}$ and stirred for $23 \mathrm{~h}$. The reaction was quenched with an aqueous saturated $\mathrm{NaHCO}_{3}$ solution and the mixture diluted with EtOAc. The organic and aqueous phases were separated, and the aqueous phase was extracted with EtOAc (4 h). The combined organic layers were washed with brine, dried with $\mathrm{Na}_{2} \mathrm{SO}_{4}$, filtered and dried in vacuo. The crude product was dissolved in dry THF $(1.5 \mathrm{~mL})$, and 5-hydroxytryptamine hydrochloride ( $33.6 \mathrm{mg}, 0.158 \mathrm{mmol}), \mathrm{Et}_{3} \mathrm{~N}(22 \mu \mathrm{L}, 0.158 \mathrm{mmol})$ in dry THF $(0.5 \mathrm{~mL})$ and $\mathrm{Ti}(\mathrm{OiPr})_{4}(50 \mu \mathrm{L}, 0.171 \mathrm{mmol})$ were added. After $7 \mathrm{~h}$, TFA $(22 \mu \mathrm{L}$, $0.290 \mathrm{mmol})$ dissolved in dry THF $(0.5 \mathrm{~mL})$ was added at $0{ }^{\circ} \mathrm{C}$, and the reaction mixture was warmed to $21^{\circ} \mathrm{C}$ and stirred for $24.5 \mathrm{~h}$.
The reaction was quenched with an aqueous saturated $\mathrm{NaHCO}_{3}$ solution and diluted with EtOAc. The organic and aqueous phases were separated, and the aqueous phase was extracted with EtOAc $(3 \times)$. The combined organic layers were washed with brine, dried with $\mathrm{Na}_{2} \mathrm{SO}_{4}$, filtered and dried in vacuo. The crude product was purified by column chromatography [heptane/EtOAc (1:1) $\rightarrow$ EtOAc/ $\mathrm{MeOH}(10: 1)]$. The dried product was dissolved in $\mathrm{CH}_{2} \mathrm{Cl}_{2}(5 \mathrm{~mL})$ and washed with aqueous $\mathrm{NH}_{4} \mathrm{OH}(5 \mathrm{~mL})$. The aqueous layer was extracted with $\mathrm{CH}_{2} \mathrm{Cl}_{2}(3 \times 5 \mathrm{~mL})$, and the combined organic layers were washed with brine, dried with $\mathrm{Na}_{2} \mathrm{SO}_{4}$, filtered and dried in vacuo to afford 7BC (27.5 mg, $0.051 \mathrm{mmol})$ as a purple solid. Yield (BORSM): $74 \% . R_{\mathrm{F}}=0.32\left(\mathrm{EtOAc} / \mathrm{Et}_{3} \mathrm{~N}, 8: 1\right) .{ }^{1} \mathrm{H} \mathrm{NMR}(400 \mathrm{MHz}$, $\left.\mathrm{CDCl}_{3}\right): \delta=7.70$ (br. s, $1 \mathrm{H}$ ), 7.62-7.55 (m, $\left.4 \mathrm{H}\right), 7.10(\mathrm{~d}, J=8.6 \mathrm{~Hz}$, $1 \mathrm{H}), 7.04(\mathrm{~d}, J=1.8 \mathrm{~Hz}, 1 \mathrm{H}), 7.02(\mathrm{dd}, J=8.2,1.9 \mathrm{~Hz}, 1 \mathrm{H}), 6.86(\mathrm{~d}$, $J=2.4 \mathrm{~Hz}, 1 \mathrm{H}), 6.83(\mathrm{~d}, J=8.2 \mathrm{~Hz}, 1 \mathrm{H}), 6.68(\mathrm{dd}, J=8.6,2.4 \mathrm{~Hz}, 1$ $\mathrm{H}), 4.53(\mathrm{dd}, J=10.7,3.0 \mathrm{~Hz}, 1 \mathrm{H}), 4.41(\mathrm{dd}, J=10.7,3.0 \mathrm{~Hz}, 1 \mathrm{H})$, $3.90(\mathrm{~s}, 3 \mathrm{H}), 3.86(\mathrm{~s}, 3 \mathrm{H}), 3.34-3.16(\mathrm{~m}, 2 \mathrm{H}), 2.66(\mathrm{t}, J=5.7 \mathrm{~Hz}, 2$ H), 2.19-1.91 (m, 5 H) ppm. ${ }^{13} \mathrm{C}$ NMR (101 MHz, $\left.\mathrm{CDCl}_{3}\right): \delta=149.6$, $149.1,148.5,148.3,140.3,136.7,130.9,129.6(q, J=32.4 \mathrm{~Hz}), 128.2$, $127.3(2 \times), 125.6(q, J=3.7 \mathrm{~Hz}, 2 \times), 124.3\left(\mathrm{q}, J=272.0 \mathrm{~Hz}, \mathrm{CF}_{3}\right)$, $119.1,111.7,111.5,111.3,110.2,108.3,103.5,56.7,56.6,56.1,56.0$, 53.4, 44.5, 44.3, 39.3, 23.1 ppm. FTIR: $\tilde{v}=3364,3305,2931,2836$, $1591,1509,1223,1140,1024,800 \mathrm{~cm}^{-1}$. HRMS (ESI): calcd. for $\left[\mathrm{C}_{30} \mathrm{H}_{30} \mathrm{~F}_{3} \mathrm{~N}_{3} \mathrm{O}_{3}+\mathrm{H}\right]^{+}$538.23216; found $538.23175(|\Delta|=0.8 \mathrm{ppm})$.

(2S,4S,6R)-2-(3,4-Dimethoxyphenyl)-6-[4-(pentafluoro- $\lambda^{6}$. sulfanyl)phenyl]-2', $3^{\prime}, 4^{\prime}, 9^{\prime}$-tetrahydrospiro[piperidine-4, $1^{\prime}$-pyrido[3,4-b]indol]-6'-ol (7Cc): $\mathrm{Et}_{3} \mathrm{~N}(19 \mu \mathrm{L}, 0.137 \mathrm{mmol})$ dissolved in dry THF $(0.5 \mathrm{~mL})$ and $\mathrm{Ti}(\mathrm{OiPr})_{4}(44 \mu \mathrm{L}, 0.149 \mathrm{mmol})$ dissolved in dry THF $(0.5 \mathrm{~mL})$ were added to a mixture of $4 \mathrm{~A}(50 \mathrm{mg}, 0.114 \mathrm{mmol})$ and 5-hydroxytryptamine hydrochloride $(29.2 \mathrm{mg}, 0.137 \mathrm{mmol})$ in dry THF ( $2 \mathrm{~mL})$. After $6 \mathrm{~h}$, TFA $(19 \mu \mathrm{L}, 0.251 \mathrm{mmol})$ dissolved in dry THF $(0.5 \mathrm{~mL})$ was added at $0{ }^{\circ} \mathrm{C}$, and the reaction mixture was warmed to $21{ }^{\circ} \mathrm{C}$ and stirred for $20 \mathrm{~h}$. The reaction was quenched with $\mathrm{NaHCO}_{3}$ and the mixture diluted with EtOAc. The organic layer was separated, and the aqueous phase was extracted with EtOAc $(4 \times)$. The combined organic layers were washed with brine, dried with $\mathrm{Na}_{2} \mathrm{SO}_{4}$, filtered and dried in vacuo. The crude product was purified by column chromatography [heptane/EtOAc (1:1) $\rightarrow$ EtOAc/ $\mathrm{MeOH}(10: 1)]$, and the dried product was dissolved in $\mathrm{CH}_{2} \mathrm{Cl}_{2}(5 \mathrm{~mL})$ and washed with aqueous $\mathrm{NH}_{4} \mathrm{OH}(5 \mathrm{~mL})$. The aqueous phase was extracted with $\mathrm{CH}_{2} \mathrm{Cl}_{2}(3 \times 5 \mathrm{~mL})$, and the combined organic layers were washed with brine, dried with $\mathrm{Na}_{2} \mathrm{SO}_{4}$, filtered and dried in vacuo to afford 7Cc (32.4 mg, $0.054 \mathrm{mmol})$ as a purple solid. Yield (BORSM): $76 \% . R_{\mathrm{F}}=0.37\left(\mathrm{EtOAc} / \mathrm{Et}_{3} \mathrm{~N}, 8: 1\right) .{ }^{1} \mathrm{H} \mathrm{NMR}(500 \mathrm{MHz}$, $\left.\mathrm{CDCl}_{3}\right): \delta=7.81$ (br. s, $\left.1 \mathrm{H}\right), 7.71-7.66(\mathrm{~m}, 2 \mathrm{H}), 7.59-7.54(\mathrm{~m}, 2 \mathrm{H})$, $7.08(\mathrm{~d}, J=8.6 \mathrm{~Hz}, 1 \mathrm{H}), 7.04(\mathrm{~d}, J=1.9 \mathrm{~Hz}, 1 \mathrm{H}), 7.01$ (dd, $J=8.2$, $1.9 \mathrm{~Hz}, 1 \mathrm{H}), 6.84(\mathrm{~d}, J=2.4 \mathrm{~Hz}, 1 \mathrm{H}), 6.82(\mathrm{~d}, J=8.3 \mathrm{~Hz}, 1 \mathrm{H}), 6.67$ $(\mathrm{dd}, J=8.6,2.4 \mathrm{~Hz}, 1 \mathrm{H}), 4.54-4.50(\mathrm{~m}, 1 \mathrm{H}), 4.41(\mathrm{dd}, J=11.2$, $2.2 \mathrm{~Hz}, 1 \mathrm{H}), 3.87(\mathrm{~s}, 3 \mathrm{H}), 3.85(\mathrm{~s}, 3 \mathrm{H}), 3.29-3.16(\mathrm{~m}, 2 \mathrm{H}), 2.62(\mathrm{t}$, $J=5.6 \mathrm{~Hz}, 2 \mathrm{H}), 2.13-1.90(\mathrm{~m}, 5 \mathrm{H}) \mathrm{ppm} .{ }^{13} \mathrm{C} \mathrm{NMR}\left(101 \mathrm{MHz}, \mathrm{CDCl}_{3}\right)$ : $\delta=153.0$ (quint, $J=16.9 \mathrm{~Hz}$ ), 149.6, 149.2, 148.5, 148.3, 140.2, 136.7, 130.9, 128.2, $127.2(2 \times), 126.3$ (quint, $J=4.2 \mathrm{~Hz}, 2 \times$ ), 119.1, 111.7, $111.5,111.3,110.2,108.4,103.5,56.5,56.4,56.1,56.1,53.3,44.6$, 44.3, 39.3, 23.1 ppm. FTIR: $\tilde{v}=3367,2961,2839,1592,1516,1260$, $103,799 \mathrm{~cm}^{-1}$. HRMS (ESI): calcd. for $\left[\mathrm{C}_{29} \mathrm{H}_{30} \mathrm{~F}_{5} \mathrm{~N}_{3} \mathrm{O}_{3} \mathrm{~S}+\mathrm{H}\right]^{+}$ 596.20116; found $596.20063(|\Delta|=0.9 \mathrm{ppm})$.

General Procedure for the Synthesis of Compounds 7Ad-Cd: A solution of $\mathrm{Et}_{3} \mathrm{~N}$ (1.20 equiv.) in dry THF $(0.5 \mathrm{~mL})$ and a solution of $\mathrm{Ti}(\mathrm{OiPr})_{4}$ (1.30 equiv.) in dry THF $(0.5 \mathrm{~mL})$ were added to a mixture of piperidin-4-one $\mathbf{4 A - C}$ (1.00 equiv.) and 5-fluorotryptamine hydrochloride (1.20 equiv.) in dry THF $(2 \mathrm{~mL})$ at $21^{\circ} \mathrm{C}$ under argon. After 4-7 h, TfOH (3.00 equiv. for 7 Ad and 7Bd and 3.50 equiv. for $\mathbf{7 C d}$ ) dissolved in dry THF $(0.5 \mathrm{~mL})$ was added at $0{ }^{\circ} \mathrm{C}$, and the reaction 
mixture was warmed to $21{ }^{\circ} \mathrm{C}$ and stirred for $22-25 \mathrm{~h}$. The reaction was quenched with a saturated $\mathrm{NaHCO}_{3}$ solution and the mixture diluted with EtOAc. The layers were separated, and the aqueous phase was extracted with EtOAc $(3 \times)$. The combined organic layers were washed with brine, dried with $\mathrm{Na}_{2} \mathrm{SO}_{4}$, filtered and concentrated in vacuo. The crude product was purified by column chromatography [heptane/EtOAc (2:1) $\rightarrow$ EtOAc/MeOH (10:1)], and the dried product was dissolved in $\mathrm{CH}_{2} \mathrm{Cl}_{2}(5 \mathrm{~mL})$ and washed with aqueous $\mathrm{NH}_{4} \mathrm{OH}(5 \mathrm{~mL})$. The aqueous phase was extracted with $\mathrm{CH}_{2} \mathrm{Cl}_{2}(3 \times 5 \mathrm{~mL})$, and the combined organic layers were washed with brine, dried with $\mathrm{Na}_{2} \mathrm{SO}_{4}$, filtered and dried in vacuo to afford compounds 7Ad-Cd.

(2S,4S,6R)-2-(3,4-Dimethoxyphenyl)-6'-fluoro-6-(4-fluoro-

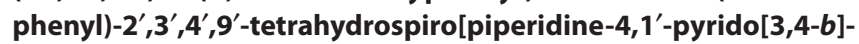
indole] (7Ad): According to the general procedure, the reaction of piperidin-4-one 4A (50 mg, $0.152 \mathrm{mmol}$ ) afforded 7Ad $(46.1 \mathrm{mg}$, $0.094 \mathrm{mmol}$ ) as a yellow solid. Yield (BORSM): $74 \% . R_{\mathrm{F}}=0.37$ (heptane/EtOAc/Et $\left.{ }_{3} \mathrm{~N}, 4: 4: 1\right) .{ }^{1} \mathrm{H}$ NMR $\left(500 \mathrm{MHz}, \mathrm{CDCl}_{3}\right): \delta=7.93$ (br. s, 1 H), 7.50-7.43 (m, $2 \mathrm{H}), 7.20-7.16(\mathrm{~m}, 1 \mathrm{H}), 7.10$ (dd, $J=9.4,2.5 \mathrm{~Hz}$, $1 \mathrm{H}), 7.04(\mathrm{~d}, J=2.0 \mathrm{~Hz}, 1 \mathrm{H}), 7.02-6.98(\mathrm{~m}, 3 \mathrm{H}), 6.86(\mathrm{td}, J=9.2$, $2.5 \mathrm{~Hz}, 1 \mathrm{H}), 6.82(\mathrm{~d}, J=8.2 \mathrm{~Hz}, 1 \mathrm{H}), 4.46-4.43(\mathrm{~m}, 1 \mathrm{H}), 4.40(\mathrm{dd}$, $J=10.8,3.1 \mathrm{~Hz}, 1 \mathrm{H}), 3.91(\mathrm{~s}, 3 \mathrm{H}), 3.86(\mathrm{~s}, 3 \mathrm{H}), 3.25(\mathrm{t}, J=5.8 \mathrm{~Hz}$, $2 \mathrm{H}), 2.69(\mathrm{t}, J=5.8 \mathrm{~Hz}, 2 \mathrm{H}), 2.09-1.93(\mathrm{~m}, 4 \mathrm{H}), 1.72$ (br. $\mathrm{s}, 2 \mathrm{H}$ ) ppm. ${ }^{13} \mathrm{C}$ NMR $\left(126 \mathrm{MHz}, \mathrm{CDCl}_{3}\right): \delta=162.1(\mathrm{~d}, J=245.2 \mathrm{~Hz}), 157.9$ $(\mathrm{d}, J=234.3 \mathrm{~Hz}), 149.1,148.4,141.4,140.4,137.1,132.1,128.4(\mathrm{~d}$, $J=7.9 \mathrm{~Hz}, 2 \times), 127.9(\mathrm{~d}, J=9.8 \mathrm{~Hz}), 119.0,115.4(\mathrm{~d}, J=21.1 \mathrm{~Hz}$, $2 \times), 111.4(d, J=9.4 \mathrm{~Hz}), 111.2,110.1,109.9(\mathrm{~d}, J=26.0 \mathrm{~Hz}), 109.1$ (d, $J=4.3 \mathrm{~Hz}$ ), 103.4 (d, $J=23.2 \mathrm{~Hz}), 56.6,56.3,56.1,56.1,53.3,45.0$, 45.0, 39.3, 23.2 ppm. FTIR: $\tilde{v}=3362,2930,2838,1601,1508,1225$, 1139, 1025, $798 \mathrm{~cm}^{-1}$. HRMS (ESI): calcd. for $\left[\mathrm{C}_{29} \mathrm{H}_{29} \mathrm{~F}_{2} \mathrm{~N}_{3} \mathrm{O}_{2}+\mathrm{H}\right]^{+}$ 490.23155; found $490.23061(|\Delta|=0.9 \mathrm{ppm})$.

(2S,4S,6R)-2-(3,4-Dimethoxyphenyl)-6'-fluoro-6-[4-(trifluoromethyl)phenyl]-2', $3^{\prime}, 4^{\prime}, 9^{\prime}$-tetrahydrospiro[piperidine-4, $1^{\prime}$-pyrido[3,4-b]indole] (7Bd): According to the general procedure, the reaction of piperidin-4-one 4B (50 $\mathrm{mg}, 0.132 \mathrm{mmol}$ ) afforded 7Bd ( $21.9 \mathrm{mg}, 0.041 \mathrm{mmol}$ ) as a yellow solid. In this case, after applying the general procedure, the crude product was purified for a second time by ion-exchange column chromatography (ISOLUTE SCX-2). The dried product was dissolved in $\mathrm{CH}_{2} \mathrm{Cl}_{2}(5 \mathrm{~mL})$ and washed with aqueous $\mathrm{NH}_{4} \mathrm{OH}(5 \mathrm{~mL})$. The aqueous phase was extracted with $\mathrm{CH}_{2} \mathrm{Cl}_{2}(3 \times 5 \mathrm{~mL})$, and the combined organic layers were washed with brine, dried with $\mathrm{Na}_{2} \mathrm{SO}_{4}$, filtered and dried in vacuo. Yield (BORSM): $37 \% . R_{\mathrm{F}}=0.41$ (heptane/EtOAc/Et ${ }_{3} \mathrm{~N}, 4: 4: 1$ ). ${ }^{1} \mathrm{H}$ NMR (500 MHz, $\left.\mathrm{CDCl}_{3}\right): \delta=7.94$ (br. s, $\left.1 \mathrm{H}\right), 7.65-7.55$ (m, $\left.4 \mathrm{H}\right), 7.20-7.15$ $(\mathrm{m}, 1 \mathrm{H}), 7.10$ (dd, $J=9.4,2.4 \mathrm{~Hz}, 1 \mathrm{H}), 7.08-7.04(\mathrm{~m}, 1 \mathrm{H}), 7.06-7.00$ $(\mathrm{m}, 1 \mathrm{H}), 6.86(\mathrm{td}, J=9.2,2.6 \mathrm{~Hz}, 1 \mathrm{H}), 6.83(\mathrm{~d}, J=8.3 \mathrm{~Hz}, 1 \mathrm{H}), 4.57-$ $4.52(\mathrm{~m}, 1 \mathrm{H}), 4.45-4.41(\mathrm{~m}, 1 \mathrm{H}), 3.91(\mathrm{~s}, 3 \mathrm{H}), 3.86(\mathrm{~s}, 3 \mathrm{H}), 3.29-$ $3.22(\mathrm{~m}, 2 \mathrm{H}), 2.70(\mathrm{t}, J=5.5 \mathrm{~Hz}, 2 \mathrm{H}), 2.09-1.92(\mathrm{~m}, 4 \mathrm{H}), 1.80$ (br. s, $2 \mathrm{H})$ ppm. ${ }^{13} \mathrm{C}$ NMR $\left(101 \mathrm{MHz}, \mathrm{CDCl}_{3}\right): \delta=157.9(\mathrm{~d}, J=234.3 \mathrm{~Hz})$, 149.2, 148.5, 148.4, 141.1, 136.8, 132.1, 129.7 (q, $J=32.6 \mathrm{~Hz}$ ), 127.9 $(\mathrm{d}, J=9.6 \mathrm{~Hz}), 127.3(2 \times), 125.6(\mathrm{q}, J=3.4 \mathrm{~Hz}, 2 \times), 124.3(\mathrm{q}, J=$ $\left.271.5 \mathrm{~Hz}, \mathrm{CF}_{3}\right), 119.0,111.4(\mathrm{~d}, J=9.6 \mathrm{~Hz}), 111.3,110.2,110.0(\mathrm{~d}, J=$ $26.0 \mathrm{~Hz}), 109.1(\mathrm{~d}, J=4.5 \mathrm{~Hz}), 103.4(\mathrm{~d}, J=23.2 \mathrm{~Hz}), 56.6,56.5,56.1$, 56.1, 53.2, 44.6, 44.4, 39.3, 23.1 ppm. FTIR: $\tilde{v}=3362,2935,2837$, $1586,1514,1261,1017,799 \mathrm{~cm}^{-1}$. HRMS (ESI): calcd. for $\left[\mathrm{C}_{30} \mathrm{H}_{29} \mathrm{~F}_{4} \mathrm{~N}_{3} \mathrm{O}_{2}+\mathrm{H}\right]^{+}$540.22734; found 540.22741 (| $\left.\Delta \mid=0.1 \mathrm{ppm}\right)$.

(2S,4S,6R)-2-(3,4-Dimethoxyphenyl)-6'-fluoro-6-[4-(pentafluoro- $\lambda^{6}$-sulfanyl)phenyl]-2', $3^{\prime}, 4^{\prime}, 9^{\prime}$-tetrahydrospiro[piperidine-4, $\mathbf{1}^{\prime}$-pyrido[3,4-b]indole] (7Cd): According to the general procedure, the reaction of piperidin-4-one $4 \mathrm{C}(50 \mathrm{mg}, 0.114 \mathrm{mmol})$ afforded $\mathbf{7 C d}(27.6 \mathrm{mg}, 0.046 \mathrm{mmol})$ as a yellow solid. Yield (BORSM): $52 \% . R_{\mathrm{F}}=0.25$ (heptane/EtOAc/Et ${ }_{3} \mathrm{~N}, 4: 4: 1$ ). ${ }^{1} \mathrm{H}$ NMR $\left(500 \mathrm{MHz}, \mathrm{CDCl}_{3}\right): \delta=8.02$ (br. s, $\left.1 \mathrm{H}\right), 7.71(\mathrm{~d}, J=8.8 \mathrm{~Hz}, 2 \mathrm{H}), 7.58$ $(\mathrm{d}, J=8.4 \mathrm{~Hz}, 2 \mathrm{H}), 7.20-7.15(\mathrm{~m}, 1 \mathrm{H}), 7.10(\mathrm{dd}, J=9.5,2.5 \mathrm{~Hz}, 1$ $\mathrm{H}), 7.04(\mathrm{~d}, J=2.0 \mathrm{~Hz}, 1 \mathrm{H}), 7.02(\mathrm{dd}, J=8.2,2.0 \mathrm{~Hz}, 1 \mathrm{H}), 6.87(\mathrm{td}$, $J=9.1,2.6 \mathrm{~Hz}, 1 \mathrm{H}), 6.83(\mathrm{~d}, J=8.2 \mathrm{~Hz}, 1 \mathrm{H}), 4.54(\mathrm{dd}, J=7.6,6.1 \mathrm{~Hz}$, $1 \mathrm{H}), 4.42(\mathrm{dd}, J=11.0,2.2 \mathrm{~Hz}, 1 \mathrm{H}), 3.91(\mathrm{~s}, 3 \mathrm{H}), 3.86(\mathrm{~s}, 3 \mathrm{H}), 3.31-$ $3.20(\mathrm{~m}, 2 \mathrm{H}), 2.69(\mathrm{t}, J=5.7 \mathrm{~Hz}, 2 \mathrm{H}), 2.13-1.96(\mathrm{~m}, 4 \mathrm{H}) \mathrm{ppm} .{ }^{13} \mathrm{C}$ NMR $\left(101 \mathrm{MHz}, \mathrm{CDCl}_{3}\right): \delta=157.9(\mathrm{~d}, J=234.4 \mathrm{~Hz}$ ), 153.0 (quint, $J=$ $16.9 \mathrm{~Hz}), 149.2,148.5,148.4,141.0,136.8,132.1,127.9(\mathrm{~d}, J=9.6 \mathrm{~Hz})$, $127.2(2 \times), 126.3$ (quint, $J=4.5 \mathrm{~Hz}, 2 \times), 119.0,111.4(\mathrm{~d}, J=9.8 \mathrm{~Hz}$ ), 111.3, 110.1, $110.0(\mathrm{~d}, J=26.6 \mathrm{~Hz}), 109.2(\mathrm{~d}, J=4.5 \mathrm{~Hz}), 103.4(\mathrm{~d}$, $J=23.4 \mathrm{~Hz}), 56.4,56.3,56.1(2 \times), 53.2,44.9,44.6,39.3,23.2 \mathrm{ppm}$. FTIR: $\tilde{v}=3367,2962,2839,1588,1515,1260,1022,795 \mathrm{~cm}^{-1}$. HRMS (ESI): calcd. for $\left[\mathrm{C}_{29} \mathrm{H}_{29} \mathrm{~F}_{6} \mathrm{~N}_{3} \mathrm{O}_{2} \mathrm{~S}+\mathrm{H}\right]^{+}$598.19536; found 598.19629 $(|\Delta|=1.6 \mathrm{ppm})$.

General Procedure for the Synthesis of Compounds 12 and 13: $\mathrm{Ti}(\mathrm{OiPr})_{4}$ was added to a mixture of piperidin-4-one 4A (1.00 equiv.) and the amine $[1.20$ equiv., $2-(1 H$-indol-2-yl)ethan-1-amine (9) for 12 and 2-(1H-pyrrol-2-yl)ethan-1-amine (11) for 13] in dry THF $(3 \mathrm{~mL})$ at $21{ }^{\circ} \mathrm{C}$ under argon. After $6 \mathrm{~h}$, TFA (2.20 equiv.) was added at $0{ }^{\circ} \mathrm{C}$, and the reaction mixture was warmed to $21^{\circ} \mathrm{C}$ and stirred overnight. The reaction was quenched with a saturated $\mathrm{NaHCO}_{3}$ solution $(3 \mathrm{~mL})$ and the mixture diluted with EtOAc. The layers were separated, and the aqueous phase was extracted with EtOAc $(4 \times$ $6 \mathrm{~mL}$ ). The combined organic layers were washed with brine, dried with $\mathrm{Na}_{2} \mathrm{SO}_{4}$, filtered and concentrated in vacuo. The crude product was purified by column chromatography [heptane/EtOAc (2:1) $\rightarrow$ EtOAc], and the dried product was dissolved in $\mathrm{CH}_{2} \mathrm{Cl}_{2}(5 \mathrm{~mL})$ and washed with aqueous $\mathrm{NH}_{4} \mathrm{OH}(5 \mathrm{~mL})$. The aqueous phase was extracted with $\mathrm{CH}_{2} \mathrm{Cl}_{2}(3 \times 5 \mathrm{~mL})$, and the combined organic layers were washed with brine, dried with $\mathrm{Na}_{2} \mathrm{SO}_{4}$, filtered and dried in vacuo to afford compounds 12 and 13.

(2S,4S,6R)-2-(3,4-Dimethoxyphenyl)-6-(4-fluorophenyl)$2^{\prime}, 3^{\prime}, 4^{\prime}, 5^{\prime}$-tetrahydrospiro[piperidine-4,1'-pyrido[4,3-b]indole] (12): According to the general procedure, the reaction of piperidin4-one 4A (15 mg, $0.05 \mathrm{mmol}$ ) afforded 12 (12 mg, $0.03 \mathrm{mmol})$. Yield: $52 \% . R_{\mathrm{F}}=0.35\left(\mathrm{EtOAc} / \mathrm{Et}_{3} \mathrm{~N}, 8: 1\right) .{ }^{1} \mathrm{H}$ NMR $\left(400 \mathrm{MHz}, \mathrm{CDCl}_{3}\right): \delta=$ 7.88-7.75 (m, $2 \mathrm{H}), 7.51-7.47$ (m, $2 \mathrm{H}), 7.31-7.27(\mathrm{~m}, 1 \mathrm{H}), 7.14-7.09$ $(m, 2 H), 7.08-7.03(m, 2 H), 7.03-6.95(m, 2 H), 6.85-6.80(m, 1 H)$, 4.47-4.41 (m, $1 \mathrm{H}), 4.40(\mathrm{dd}, J=12.2,2.2 \mathrm{~Hz}, 1 \mathrm{H}), 3.90(\mathrm{~s}, 3 \mathrm{H}), 3.85$ $(\mathrm{s}, 3 \mathrm{H}), 3.26(\mathrm{t}, J=5.6 \mathrm{~Hz}, 2 \mathrm{H}), 2.74(\mathrm{t}, J=5.6 \mathrm{~Hz}, 2 \mathrm{H}), 2.60-2.39$ $(\mathrm{m}, 2 \mathrm{H}), 1.92-1.82(\mathrm{~m}, 2 \mathrm{H}) \mathrm{ppm} .{ }^{13} \mathrm{C}$ NMR $\left(101 \mathrm{MHz} \mathrm{CDCl}_{3}\right): \delta=$ 162.0 (indirect observation), 149.0, 148.2, 140.0 (indirect observation), 137.9 (indirect observation), 132.5, 131.1, $128.5(d, J=7.8 \mathrm{~Hz}$, $2 \times), 125.1,121.2,119.5,119.4,119.0,116.4,115.2(d, J=21.1 \mathrm{~Hz}$, $2 \times), 111.3,110.9,110.4,56.9,56.6,56.1(2 \times), 54.2,44.8,44.6,38.7$, 24.8 ppm. FTIR: $\tilde{v}=3366,2957,2856,1602,1508,1229,1156,1026$, $763 \mathrm{~cm}^{-1}$. HRMS (ESI): calcd. for $\left[\mathrm{C}_{29} \mathrm{H}_{31} \mathrm{~F}_{1} \mathrm{~N}_{3} \mathrm{O}_{2}+\mathrm{H}\right]^{+}$472.24003; found $472.24094(|\Delta|=1.92 \mathrm{ppm})$.

(2S,4S,6R)-2-(3,4-Dimethoxyphenyl)-6-(4-fluorophenyl)$1^{\prime}, 5^{\prime}, 6^{\prime}, 7^{\prime}$-tetrahydrospiro[piperidine-4,4'-pyrrolo[3,2-c]pyridine] (13): According to the general procedure, the reaction of piperidin-4-one 4A (40 mg, $0.12 \mathrm{mmol})$ afforded $13(22 \mathrm{mg}$, $0.062 \mathrm{mmol}$ ). Yield: $52 \% . R_{\mathrm{F}}=0.45\left(\mathrm{EtOAc} \mathrm{Et}_{3} \mathrm{~N}, 8: 1\right) .{ }^{1} \mathrm{H} \mathrm{NMR}$ $\left(400 \mathrm{MHz}, \mathrm{CDCl}_{3}\right): \delta=7.79$ (br. s, $\left.1 \mathrm{H}\right), 7.49-7.39(\mathrm{~m}, 2 \mathrm{H}), 7.06-6.95$ $(\mathrm{m}, 4 \mathrm{H}), 6.82(\mathrm{~d}, J=8.2 \mathrm{~Hz}, 1 \mathrm{H}), 6.60(\mathrm{t}, J=2.7 \mathrm{~Hz}, 1 \mathrm{H}), 6.06(\mathrm{t}$, $J=2.7 \mathrm{~Hz}, 1 \mathrm{H}), 4.33(\mathrm{dd}, J=11.3,3.5 \mathrm{~Hz}, 1 \mathrm{H}), 4.29(\mathrm{dd}, J=11.6$, $2.9 \mathrm{~Hz}, 1 \mathrm{H}), 3.90(\mathrm{~s}, 3 \mathrm{H}), 3.86(\mathrm{~s}, 3 \mathrm{H}), 3.20(\mathrm{t}, J=5.8 \mathrm{~Hz}, 2 \mathrm{H}), 2.58$ $(\mathrm{t}, J=5.8 \mathrm{~Hz}, 2 \mathrm{H}), 2.07-1.79(\mathrm{~m}, 4 \mathrm{H}), 1.68$ (br. $\mathrm{s}, 1 \mathrm{H}) \mathrm{ppm} .{ }^{13} \mathrm{C}$ NMR (101 MHz, $\left.\mathrm{CDCl}_{3}\right): \delta=162.0(\mathrm{~d}, J=244.4 \mathrm{~Hz}), 149.0,148.1$, $141.1(\mathrm{~d}, J=3.0 \mathrm{~Hz}), 138.0,128.4(\mathrm{~d}, J=7.9 \mathrm{~Hz}, 2 \times), 124.8,118.9$, 116.0, $115.1(\mathrm{~d}, J=21.1 \mathrm{~Hz}, 2 \times), 111.2,110.9,110.2,104.5,56.8$, 56.5, $56.1(2 \times), 53.5,46.4,46.3,38.9,24.3$ ppm. FTIR: $\tilde{v}=3379,2930$, 
2836, 1604, 1508, 1227, 1156, 1026, $765 \mathrm{~cm}^{-1}$. HRMS (ESI): calcd. for $\left[\mathrm{C}_{25} \mathrm{H}_{29} \mathrm{~F}_{1} \mathrm{~N}_{3} \mathrm{O}_{2}+\mathrm{H}\right]^{+}$422.22438; found $422.22591(|\Delta|=3.63$ ppm).

Supporting Information (see footnote on the first page of this article): Full experimental details for the preparation of the compounds described herein, characterization of new compounds and ${ }^{1} \mathrm{H}$ and ${ }^{13} \mathrm{C}$ NMR spectra.

\section{Acknowledgments}

This work has been supported by the FP7 Marie Curie Actions of the European Commission via the ITN ECHONET Network (MCITN-2012-316379).

Keywords: Enantioselectivity · Diastereoselectivity · Spiro compounds . Nitrogen heterocycles - Library synthesis . Multicomponent reactions

[1] a) G. Müller, T. Berkenbosch, J. Benningshof, D. Stumpfe, J. Bajorath, Chem. Eur. J. 10.1002/chem.201604714; b) Y. J. Zheng, C. M. Tice, S. B. Singh, Bioorg. Med. Chem. Lett. 2014, 24, 3673-3682; c) R. Rios, Chem. Soc. Rev. 2012, 41, 1060-1074.

[2] For iboluteine, see: a) B. Q. Tang, W. J. Wang, X. J. Huang, G. Q. Li, L. Wang, R. W. Jiang, T. T. Yang, L. Shi, X. Q. Zhang, W. C. Ye, J. Nat. Prod. 2014, 77, 1839-1846; b) G. Y. Zhao, X. G. Xie, H. Y. Sun, Z. Y. Yuan, Z. L. Zhong, S. C. Tang, X. G. She, Org. Lett. 2016, 18, 2447-2450; for fluspirilene, see: c) A. Schmidt, M. Marchetti, P. Eilbracht, Tetrahedron 2004, 60, 11487-11492; d) C. Botteghi, M. Marchetti, S. Paganelli, F. PersiPaoli, Tetrahedron 2001, 57, 1631-1637; for fenspiride hydrochloride, see: R. Somanathan, I. A. Rivero, G. I. Nuñez, L. H. Hellberg, Synth. Commun. 1994, 24, 1483-1487.

[3] C. M. Marson, Chem. Soc. Rev. 2011, 40, 5514-5533.

[4] a) P. Nithya, F. R. N. Khan, S. M. Roopan, U. Shankar, J. S. Jin, Chem. Pap. 2011, 65, 743-746; b) N. Rameshkumar, A. Veena, R. Llavarasan, M. Adiraj, P. Shanmugapandiyan, S. K. Sridhar, Biol. Pharm. Bull. 2003, 26, 188-193.

[5] a) D. O'Hagan, Chem. Soc. Rev. 2008, 37, 308-319; b) E. P. Gillis, K. J. Eastman, M. D. Hill, D. J. Donnelly, N. A. Meanwell, J. Med. Chem. 2015, $58,8315-8359$; c) for a review on fluorine in pharmaceuticals, see: $\mathrm{K}$. Muller, C. Faeh, F. Diederich, Science 2007, 317, 1881-1886; d) for a review on fluorine-containing agrochemicals, see: T. Fujiwara, D. O'Hagan, J. Fluorine Chem. 2014, 167, 16-29; e) F. Giornal, S. Pazenok, L. Rodefeld, N. Lui, J. P. Vors, F. R. Leroux, J. Fluorine Chem. 2013, 152, 2-11.

[6] a) V. De Matteis, O. Dufay, D. C. J. Waalboer, F. L. van Delft, J. Tiebes, F. P. J. T. Rutjes, Eur. J. Org. Chem. 2007, 2667-2675; b) V. De Matteis, F. L. van Delft, J. Tiebes, F. P. J. T. Rutjes, Eur. J. Org. Chem. 2006, 1166-1176.

[7] J. M. M. Verkade, F. van der Pijl, M. A. J. H. P. Willems, P. J. L. M. Quaedflieg, F. L. van Delft, F. P. J. T. Rutjes, J. Org. Chem. 2009, 74, 3207-3210.

[8] European Lead Factory home page, https://www.europeanleadfactory. eu/ (accessed November 8, 2016).
[9] For multi-component Mannich reactions catalysed by L-proline, see: a) A. Cordova, Chem. Eur. J. 2004, 10, 1987-1997; b) I. Ibrahem, J. Casas, A. Cordova, Angew. Chem. Int. Ed. 2004, 43, 6528-6531; Angew. Chem. 2004, $116,6690$.

[10] For examples of active molecules containing the 3,4-dimethoxyphenyl group, see: Q. S. Yu, W. M. Luo, J. Deschamps, H. W. Holloway, T. Kopajtic, J. L. Katz, A. Brossi, N. H. Greig, ACS Med. Chem. Lett. 2010, 1, 105-109; S. J. Min, Y. S. Cho, J. K. Lee, A. N. Pae, Y. W. Son, Method of preparing tetrabenazine and dihydrotetrabenazine, U.S. Pat. 2013197227, August 1, 2013; D. Albani, R. Arosio, V. Merli, Process for preparing N-methyl-3,4dimethoxyphenylethylamine, U.S. Pat. 2009171110, July 2, 2009; O. C. Pacheco, A. L. L. Garcia, Process for preparing donepezil hydrochloride forms I and III, and an intermediate compound thereof, WO 2015109377, July 30, 2015.

[11] a) X. D. Jia, X. N. Chen, X. E. Wang, C. D. Huo, W. J. Wang, Y. Ren, X. C. Wang, Eur. J. Org. Chem. 2011, 1627-1631; b) F. Aznar, A.-B. Garcia, N. Quinones, M.-P. Cabal, Synthesis 2008, 479-484; c) F. Aznar, A.-B. Garcia, M.-P. Cabal, Adv. Synth. Catal. 2006, 348, 2443-2448; d) K. Takasu, N. Shindoh, H. Tokuyama, M. Ihara, Tetrahedron 2006, 62, 11900-11907.

[12] J. M. M. Verkade, L. J. C. van Hemert, P. J. L. M. Quaedflieg, P. L. Alsters, F. L. van Delft, F. P. J. T. Rutjes, Tetrahedron Lett. 2006, 47, 8109-8113.

[13] The reactions for the syntheses of compounds $\mathbf{4 B}$ and $\mathbf{4 C}$ were not optimized.

[14] a) A. Pictet, T. Spengler, Ber. Dtsch. Chem. Ges. 1911, 44, 2030-2036; b) for a review, see: J. Stöckigt, A. P. Antonchick, F. R. Wu, H. Waldmann, Angew. Chem. Int. Ed. 2011, 50, 8538-8564; Angew. Chem. 2011, 123, 8692; c) for an enantioselective version, see: N. Mittal, D. X. Sun, D. Seidel, Org. Lett. 2014, 16, 1012-1015; d) for a catalytic asymmetric version, see: J. Seayad, A. M. Seayad, B. List, J. Am. Chem. Soc. 2006, 128, 1086-1087; e) for a review on the oxa-Pictet-Spengler reaction, see: E. L. Larghi, T. S. Kaufman, Synthesis 2006, 187-220.

[15] For some examples of the intermolecular Pictet-Spengler reaction with phenethylamines, see: a) M. P. Chelopo, S. A. Pawar, M. K. Sokhela, T. Govender, H. G. Kruger, G. E. M. Maguire, Eur. J. Med. Chem. 2013, 66, 407-414; b) O. O. Orazi, R. A. Corral, H. Giaccio, J. Chem. Soc. Perkin Trans. 1 1986, 1977-1982; c) H. A. Bates, K. Bagheri, P. M. Vertino, J. Org. Chem. 1986, 51, 3061-3063.

[16] a) S. Nakamura, M. Tanaka, T. Taniguchi, M. Uchiyama, T. Ohwada, Org. Lett. 2003, 5, 2087-2090; b) A. Yokoyama, T. Ohwada, K. Shudo, J. Org. Chem. 1999, 64, 611-617.

[17] For the concept of steric approach control, see: W. G. Dauben, G. J. Fonken, D. S. Noyce, J. Am. Chem. Soc. 1956, 78, 2579-2582.

[18] a) J. M. Lopchuk, G. W. Gribble, Heterocycles 2011, 82, 1617-1631; b) J. P. Strachan, D. F. O'Shea, T. Balasubramanian, J. S. Lindsey, J. Org. Chem. 2000, 65, 3160-3172.

[19] a) D. Robaa, C. Enzensperger, S. E. D. Abul Azm, E. S. El Khawass, O. El Sayed, J. Lehmann, J. Med. Chem. 2010, 53, 2646-2650; b) S. G. Dawande, V. Kanchupalli, J. Kalepu, H. Chennamsetti, B. S. Lad, S. Katukojvala, Angew. Chem. Int. Ed. 2014, 53, 4076-4080; Angew. Chem. 2014, $126,4160$.

Received: November 28, 2016 